TAPROBANICA, ISSN 1800-427X. April, 2020. Vol. 09, No. 01: pp. 83-102, pls. 30-36. (C) Research Center for Climate Change, University of Indonesia, Depok, Indonesia www.taprobanica.org

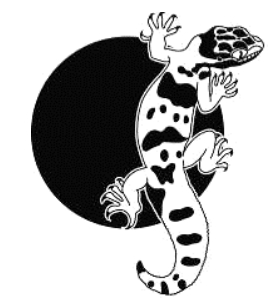

urn:Isid:zoobank.org:act:B2B21840-6D3C-46F4-A1D6-61EFFFB048DD

\title{
A NEW SPECIES OF Dendrelaphis BOULENGER, 1890 (REPTILIA: COLUBRIDAE) FROM THE WET ZONE OF SRI LANKA WITH A REDESCRIPTION OF Dendrelaphis bifrenalis (BOULENGER, 1890)
}

\author{
A. Dineth Danushka ${ }^{1}$, A. Suneth Kanishka ${ }^{1}$, A.A. Thasun Amarasinghe ${ }^{2,4}$, \\ ${\text { Gernot } \text { Vogel }^{3} \& \text { Sampath S. Seneviratne }}^{1}$
}

\footnotetext{
${ }^{1}$ Laboratory for Molecular Ecology and Evolution, Department of Zoology \& Environment Sciences, Faculty of Science, University of Colombo, Colombo 03, Sri Lanka

${ }^{2}$ Research Center for Climate Change, University of Indonesia, Gd. PAU Lt. 8.5, Kampus UI, Depok 16424, Indonesia

${ }^{3}$ Society for Southeast Asian Herpetology, Im Sand 3, D-69115 Heidelberg, Germany

${ }^{4}$ Association of Asian Herpetology (Asosiasi Herpetologi Asia), Jl. BSD Bintaro No. 88, Pondok Aren 15228, Tangerang Selatan, Indonesia

${ }^{2}$ Corresponding author. E-mail: thasun@rccc.ui.ac.id
}

\begin{abstract}
Examination of the Dendrelaphis bifrenalis populations on Sri Lanka showed that there are two populations that are morphologically different from each other. One population is distributed only in the wet zone forests (hereafter treated as wet zone population), while the other population occurs widely in the dry zone and intermediate zones (hereafter dry zone population). The type series of $D$. bifrenalis consist of 3 specimens from which the specimen representing the dry zone population was chosen as lectotype, and the wet zone population is described here as a new species. It clearly differs from $D$. bifrenalis by having a shorter snout, orbit diameter $103-114 \%$ of eye-nostril length (vs $77-$ $95 \%$ ), and larger eye, orbit diameter $21-23 \%$ of head length (vs 17-20\%). Furthermore it differs by having a temporal stripe stopping just beyond the neck ( $v s$ continues behind neck), the absence of black transverse dorsolateral bars on the anterior $1 / 4^{\text {th }}$ of body ( $v$ s prominent), a narrow and pointed snout ( $v s$ broad and flat), a divided nasal ( $v s$ single), and a ventrolateral stripe continuing up to the tail (vs stopping at the level of the anal plate). This morphological differentiation is supported by the divergence in the mitochondrial NADH dehydrogenase subunit 4 (ND4) region separating clearly with the divergence of $1.70 \pm 0.35 \%$. Also, here we resurrect $D$. effrenis (Werner, 1909) as a valid species, and $D$. sinharajensis as a junior synonym of it. The holotype of $D$. sinharajensis was chosen as the neotype of $D$. effrenis to stabilize nomenclature, and to make it an objective synonym. The third and fourth known specimens of this rare species are reported. A key of the species of the genus Dendrelaphis in Sri Lanka is provided.
\end{abstract}

Key words: Holotype, island biogeography, lectotype, neotype, syntype, systematic, taxonomy. 


\section{Introduction}

The bronzebacks, or the arboreal colubrid snake genus Dendrelaphis Boulenger, 1890 in Sri Lanka has been studied extensively for the last two centuries (Boulenger 1894, Wall 1921, Meise \& Henning 1932, Smith 1943, Deraniyagala 1955, Leviton 1970, De Silva 1980 etc.). However, most of the taxonomic issues remained unsolved until Vogel \& van Rooijen (e.g. 2008, 2011a) and van Rooijen \& Vogel (e.g. 2008a, 2012) reviewed the genus.

The first Dendrelaphis species recorded from Sri Lanka was Dendrelaphis tristis (Daudin, 1803) which was considered to be a widespread species in Sri Lanka and India, until van Rooijen \& Vogel (2008b, 2009) restricted it to the dry zone of the island and South India, while resurrecting $D$. schokari (Kuhl, 1820) for the population in the wet zone. $D$. caudolineolatus (Günther, 1869) is endemic to Sri Lanka.

D. bifrenalis (Boulenger, 1890) was considered to be widespread in Sri Lanka and India, until Vogel \& van Rooijen (2011b) restricted it to Sri Lanka. D. oliveri (Taylor, 1950), is only known from its holotype and no new records have been published for the last 70 years. The last species to be described from the island was $D$. sinharajensis Wickramasinghe, 2016. In addition to the above six species, another species, D. effrenis (Werner, 1909) was described from Sri Lanka, based on a single specimen collected from Colombo (Sri Lanka). Smith (1943) referred it to the synonymy of $D$. caudolineolatus, and it is currently regarded as a subjective synonym of $D$. caudolineatus (Gray, 1834), a Malayan member of the genus.

Dendrelaphis bifrenalis is the smallest among the Sri Lankan Dendrelaphis, and can be easily distinguished from its congeners by the presence of a red tongue and two loreal scales (De Silva 1980). Boulenger (1890) described this species based on three syntypes. However, after a critical comparison of the Dendrelaphis bifrenalis populations (live and museum specimens, see Appendix I) in Sri Lanka, we realized that there are two populations which are morphologically different from each other. One population is distributed only in the wet zone forests (hereafter treated as wet zone population), while the other population occurs widely in the dry zone and intermediate zones (hereafter dry zone population). The wet zone population is described here as a new species.

\section{Material and Methods}

Data collection. Specimens were examined in the collections of the Natural History Museum, London, UK (BMNH); the National Wildlife Research and Training Centre, Department of Wildlife Conservation, Girithale, Sri Lanka (DWC); Field Museum of Natural History, Chicago, USA (FMNH); Muséum d'histoire naturelle, Genève [Geneva], Switzerland (MHNG); Muséum National d'Histoire Naturelle, Paris, France (MNHN); Museum für Tierkunde, Dresden, Germany (MTKD); National Museum of Sri Lanka, Colombo, Sri Lanka (NMSL); Naturhistorisches Museum Wien, Vienna, Austria (NMW); National Museum of Natural History, Leiden, The Netherlands $\quad(\mathrm{RMNH}) ; \quad$ Senckenberg Forschungsinstitut und Naturmuseum, Frankfurt am Main, Germany (SMF); and Smithsonian Institution National Museum of Natural History, Washington, D.C., USA (USNM). Museum acronyms follow Uetz et al. (2019).

Morphometric and meristic data for species comparisons were obtained from examined specimens (see Appendix I). Sex was determined by ventral tail incision of adult specimens followed by the checking for presence or absence of hemipenes. Natural history data were taken from our own field observations during the last ten years, as well as published literature.

Morphometric and meristic data. The following characters were measured with a digital caliper $( \pm 0.1 \mathrm{~mm})$ : eye diameter (ED, horizontal diameter of eye); eye-nostril length (EN, distance between anterior most point of eye and middle of nostril); snout length (ES, distance between anterior most point of eye and snout); nostril diameter (ND, horizontal diameter of nostril); internarial distance (IN, least distance between nostrils); mandibleposterior eye distance (MPE, distance between posterior edge of mandible and posterior most edge of eye); interorbital width (IO, least distance between upper margins of orbits); head length (HL, distance between posterior edge of mandible and tip of snout); head width (HW, maximum width of head); snout-vent length (SVL, measured from tip of snout to anterior margin of vent); tail length (TAL, measured from anterior margin of vent to tail tip). Meristic characters were taken as follows: supralabials and infralabials (SUP and INF, first labial scale to last labial scale bordering gape); costal scales 
(counted around the body from one side of ventrals to the other in three positions, on one head length behind neck, at mid body and at one head length prior to anal plate); when counting the number of ventral scales, we counted according to the method described by Dowling (1951). We counted paired subcaudal scales from the first scale under the tail meeting its opposite subcaudal scale, to the scale before the tip of the tail.

Morphometric analyses. We conducted a principal component analysis (PCA) to examine patterns of morphometric variation of Dendrelaphis bifrenalis. A series of components, exceeding $80 \%$ of eigenvalues as a whole, were taken into account when inspecting the ordination. The principal axis method was used to extract the components followed by an orthogonal rotation. Both sexes were included in this analysis, using the following six measurements normalized to the percentages of TAL/SVL, EN/ED, ED/HL, EN/HL, HL/SVL, and HL/TAL. Prior to the ordination, those measurements were standardized by scaling them to a standard deviation of 1.0, and mean of 0.0 . In each PCA, the majority of variation was captured by the first component (Table 1). Because the first three components together accounted for a large amount of variance $(80 \%)$, we used only the first three principal components for the analysis. All analyses were performed in the statistical software environment R, v2.15.0 (R Development Core Team, 2012).

Table1. Loadings for the first four principal components (PC) of morphometric characters in Dendrelaphis bifrenalis and the new species. See text for definitions of character abbreviations.

\begin{tabular}{lrrrr}
\hline Character & \multicolumn{1}{c}{ PC1 } & \multicolumn{1}{c}{ PC2 } & \multicolumn{1}{c}{ PC3 } & \multicolumn{1}{c}{ PC4 } \\
\cline { 2 - 5 } TL/SVL & 0.0168 & 0.9913 & 0.0780 & 0.0899 \\
ED/EN & 0.9814 & -0.0098 & -0.1081 & 0.0193 \\
ED/HL & 0.1889 & -0.0282 & 0.5978 & -0.2459 \\
EN/HL & -0.0233 & -0.0260 & 0.6902 & -0.3052 \\
HL/SVL & 0.0112 & -0.0132 & 0.2012 & 0.4726 \\
HL/TL & 0.0173 & -0.1244 & 0.3287 & 0.7839 \\
$\begin{array}{l}\text { Eigenvalue } \\
\text { Proportion } \\
\text { of variance }\end{array}$ & 0.0082 & 0.0010 & 0.0002 & 0.0001 \\
\hline
\end{tabular}

DNA based species delimitation. From live specimens a $20 \mu \mathrm{l}$ sample of blood or $2 \mathrm{~mm}$ sample of tail clip was extracted to Queens's analysis buffer (Seutin et al. 1991). A sample of muscle, liver or skin tissue was extracted to $80 \%$ ethanol from museum specimens following the guidelines of the respective institute. Genomic DNA was extracted using the DNeasy Tissue Kit (Qiagen) (Fernando et al. 2016). The fourth subunits of mitochondrial nicotinamide adenine dinucleotide dehydrogenase (ND4) was amplified by polymerase chain reaction (PCR) and sequenced using Sanger sequencing. ND4 was sequenced using primers CACCTATGACT ACCAAAAGCTCATGTCGAAGC and CATT ACTTTTACTTGGATTTGCACCA (Forstner $e t$ al. 1995). The thermo cycling profile was as below: denaturation at $94^{\circ} \mathrm{C}$ for $4 \mathrm{~min}$, an initial boost of denaturation at $94^{\circ} \mathrm{C}$ for $60 \mathrm{~s}$, annealing at $42^{\circ} \mathrm{C}$ for $60 \mathrm{~s}$ and extension at $68^{\circ} \mathrm{C}$ for $90 \mathrm{~s}$, followed by 39 cycles of denaturation at $94^{\circ} \mathrm{C}$ for 30s, annealing at $48^{\circ} \mathrm{C}$ for $30 \mathrm{~s}$, extension at $72^{\circ} \mathrm{C}$ for $60 \mathrm{~s}$, and a final extension step of $72^{\circ} \mathrm{C}$ for 15min (modified after Figueroa et al. 2016). Molecular work was done at the Laboratory for Molecular Ecology and Evolution at the Department of Zoology, University of Colombo. The Sequencing services of Macrogen (South Korea) was used for sequencing. To increase the coverage of species, we used ND4 sequences of selected Dendrelaphis species available at the NCBI Genbank. The samples used and their accession numbers are given in Table 2. As for the outgroup, sequences of Chrysopelea ornata (Shaw, 1802) and C. taprobanica Smith, 1943 from Sri Lanka were used (after Figueroa et al. 2016: see Table 3). We used Geneious version 7.1.6 (Kears et al. 2012) to examine the trace files for quality, to edit sequences and multiple align sequences across taxa using ClustalW algorithm (Larkin et al. 2007). We examined appropriate models of evolution and the best way to partition gene regions using PartitionFinder ver. 1.1.0 (Lanfear et al. 2012). Phylogenetic trees were built through Maximum likelihood (ML) approach using RAxML ver. 8.1.22 (Stamatakis 2014) and Bayesian approach using MrBayes ver. 3.2.5 (Ronquist \& Huelsenbeck 2003). For ML, we conducted tree searches rapid bootstrap of 10000 replicates and thereafter a thorough ML search of 10 runs using a separate GTR evolutionary model for each partition. Invariant sites were not included in the model. We conducted a Bayesian analysis by running the MCMC chain for $20,000,000$ generations, sampling every 100 steps, with $25 \%$ of the samples discarded as burnin. We assessed the convergence using the standard deviation of split frequencies below 0.01 and checking for stationarity using Tracer ver. 1.6 (Rambaut et al. 
2014). The number of base substitutions per site was conducted using the Maximum Composite Likelihood model (Tamura et al. 2004). The analysis involved 18 nucleotide sequences. Codon positions included were $1 \mathrm{st}+2 \mathrm{nd}+3 \mathrm{rd}+$ Noncoding. All positions containing gaps and missing data were eliminated. There were a total of 620 positions in the final dataset. Evolutionary analyses were conducted in MEGA7 (Kumar et al. 2016). The obtained sequences will be deposited in NCBI GenBank.

\section{Results}

Morphometric analyses. We retained the first three components for the inspection of PCA, which entailed over $98 \%$ of the whole eigenvalues (Table 1, Fig. 1: the eigenvalues were allocated $86.6 \%, 10.4 \%$, and $1.8 \%$ on component 1, 2, and 3 respectively. The multivariate PCA plots separated Dendrelaphis bifrenalis and the new species into two morphometrically distinct clusters (Fig. 1). The first axis was highly correlated with several measurements, where ED/EN (loading value: 0.98 ) among the six measurements. The second axis was characterized by TL/SVL (0.99).

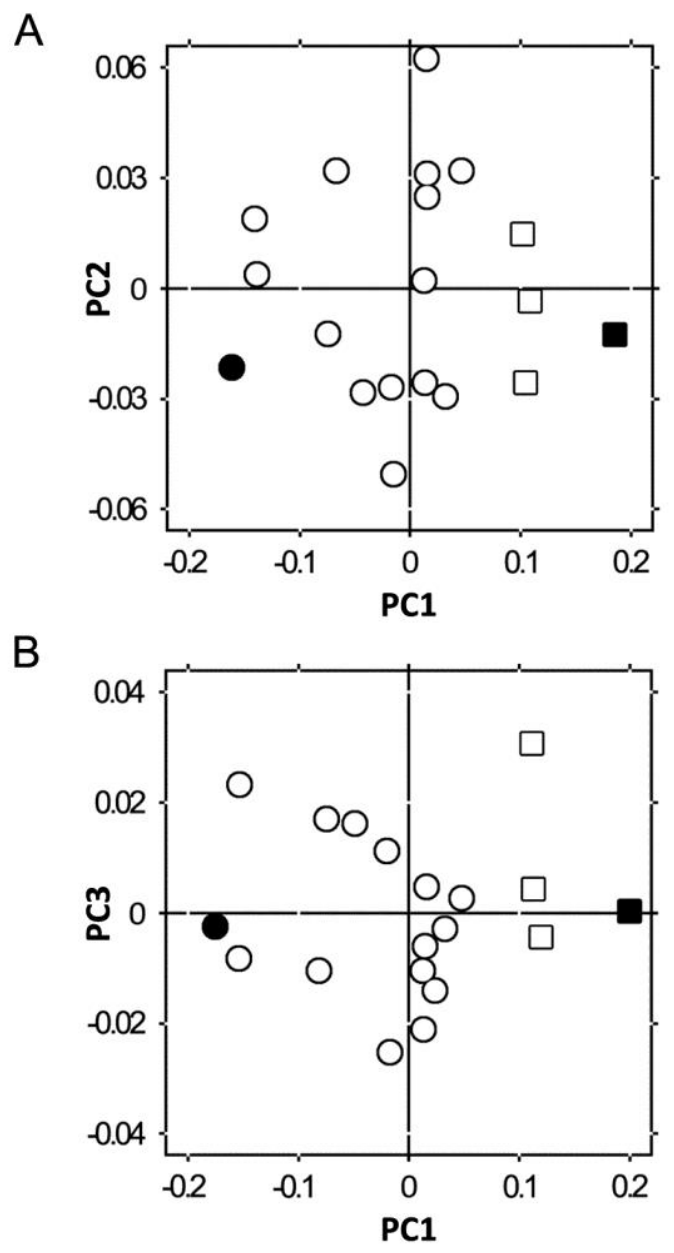

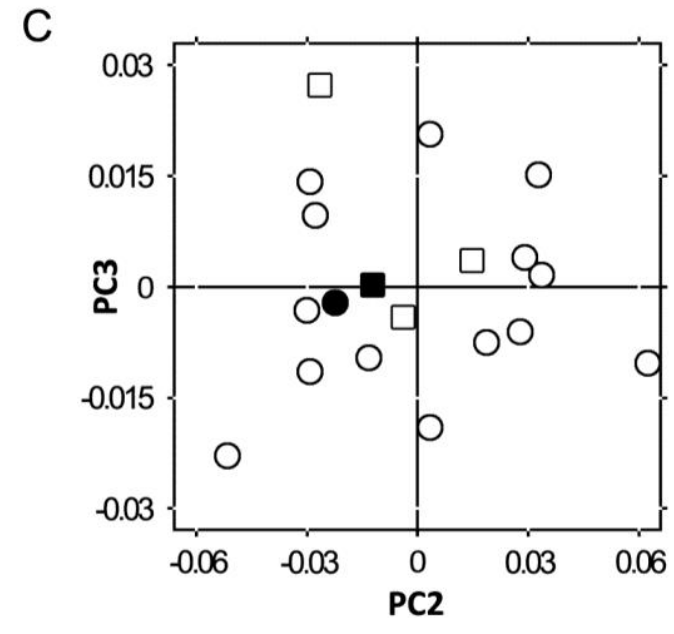

Figure 1. Morphometric analysis of Dendrelaphis bifrenalis (circles), D. wickrorum sp. nov. (squares): (A) PC1 vs. PC2; (B) PC1 vs. PC3; (C) PC2 vs. PC3; The filled symbol represents the examined lectotype and holotype respectively.

The third axis was ED/HL (0.60). All the specimens of the new species are distinctively distributed along the first, second, and third axis from fifteen $D$. bifrenalis specimens. According to this multivariate trait distribution, the new species is characterized by relatively shorter eye-nostril length (EN), larger eye (ED), and shorter tail (TL) compared to D. bifrenalis.

Phylogenetic analysis. We studied sequences of 14 specimens of Dendrelaphis from Sri Lanka, India and Southeast Asia (Table 2). The final alignment used for the phylogenetic analysis comprised 620 bp segment of the mitochondrial ND4 region, about 170 variable sites were observed within the cluster (all data given for ingroup only). The partitioned $\mathrm{ML}$ and Bayesian trees showed similar topologies. In both analyses, there were several short internodes, however, the clades relevant to the Dendrelaphis species in question were well supported (Fig. 2). The monophyly of the genus was strongly supported as well (Bootstrap value of $95 \%$ and Bayesian posterior probability of 1). The sequence of $D$. sinharajensis was poor due to the degraded nature of the tissue sample. Therefore we removed it from all trees.

The new species separated well and placed as the sister node to D. bifrenalis $(100 \%$ bootstrap support and Bayesian posterior probability of 1: Fig. 2). Together the $D$. bifrenalis-new species clade was sister to widespread East Indian-Southeast Asian bronzebacks. The remaining members of Dendrelaphis that were included in the analysis 
and are found in Sri Lanka formed weakly supported clades. The general topology of the phylogenetic relationships resulting from our analyses was consistent with results reported in previous studies (Figueroa et al. 2016). The numbers of base substitutions per site between sequences are shown in Table 3. The observed $p$-distances among members of $D$. bifrenalis complex varied from $1.31 \%$ to $2.10 \%$ of substitutions with $1.7 \%( \pm 0.35)$ divergence.

Table 2. Voucher and GenBank data on the Dendrelaphis and Chrysopelea specimens used in this study. GenBank accession numbers are given; NP, national park; FR, forest reserve; R, resort; "—" = unknown.

\begin{tabular}{|c|c|c|c|c|}
\hline Species & GenBank AN & Voucher ID & Locality & Reference \\
\hline D. subocularis & KX660623.1 & LSUHC7429 & - & Figueroa et al. 2016 \\
\hline D. tristis & КС347493.1 & RAP0492 & Bundala NP, Sri Lanka & Pyron et al. 2013 \\
\hline D. schokari & КC347497.1 & RAP047 & Hiyare Forest, Sri Lanka & Pyron et al. 2013 \\
\hline D. pictus & KX660582.1 & CAS210338 & - & Figueroa et al. 2016 \\
\hline D. marenae & KX660640.1 & KU324549 & - & Figueroa et al. 2016 \\
\hline D. haasi & KX660622.1 & LSUHC10042 & - & Figueroa et al. 2016 \\
\hline D. cyanochloris & KX660621.1 & LSUHC6768 & - & Figueroa et al. 2016 \\
\hline D. striatus & KX660625.1 & LSUHC4792 & - & Figueroa et al. 2016 \\
\hline D. striatus & KX660624.1 & LSUHC10012 & - & Figueroa et al. 2016 \\
\hline D. bifrenalis & D03ND4_ND4 & not collected & Waahalkada, Sri Lanka & this study \\
\hline D. bifrenalis & D04ND4_ND4 & not collected & Nilgala, Sri Lanka & this study \\
\hline D. wickrorum sp.nov. & D01ND4_ND4 & not collected & Ambagaspitiya, Sri Lanka & this study \\
\hline D. wickrorum sp.nov. & КС347509.1 & RAP0455 & Kanneliya FR, Sri Lanka & Pyron et al. 2013 \\
\hline D. caudolineolatus & KC347518.1 & RAP0508 & Rambukpitiya, Sri Lanka & Pyron et al. 2013 \\
\hline C. taprobanica & KC347508.1 & RAP0538 & Kandalama R, Sri Lanka & Pyron et al. 2013 \\
\hline C. ornata & КС347496.1 & RAP0433 & Kanneliya FR, Sri Lanka & Pyron et al. 2013 \\
\hline
\end{tabular}

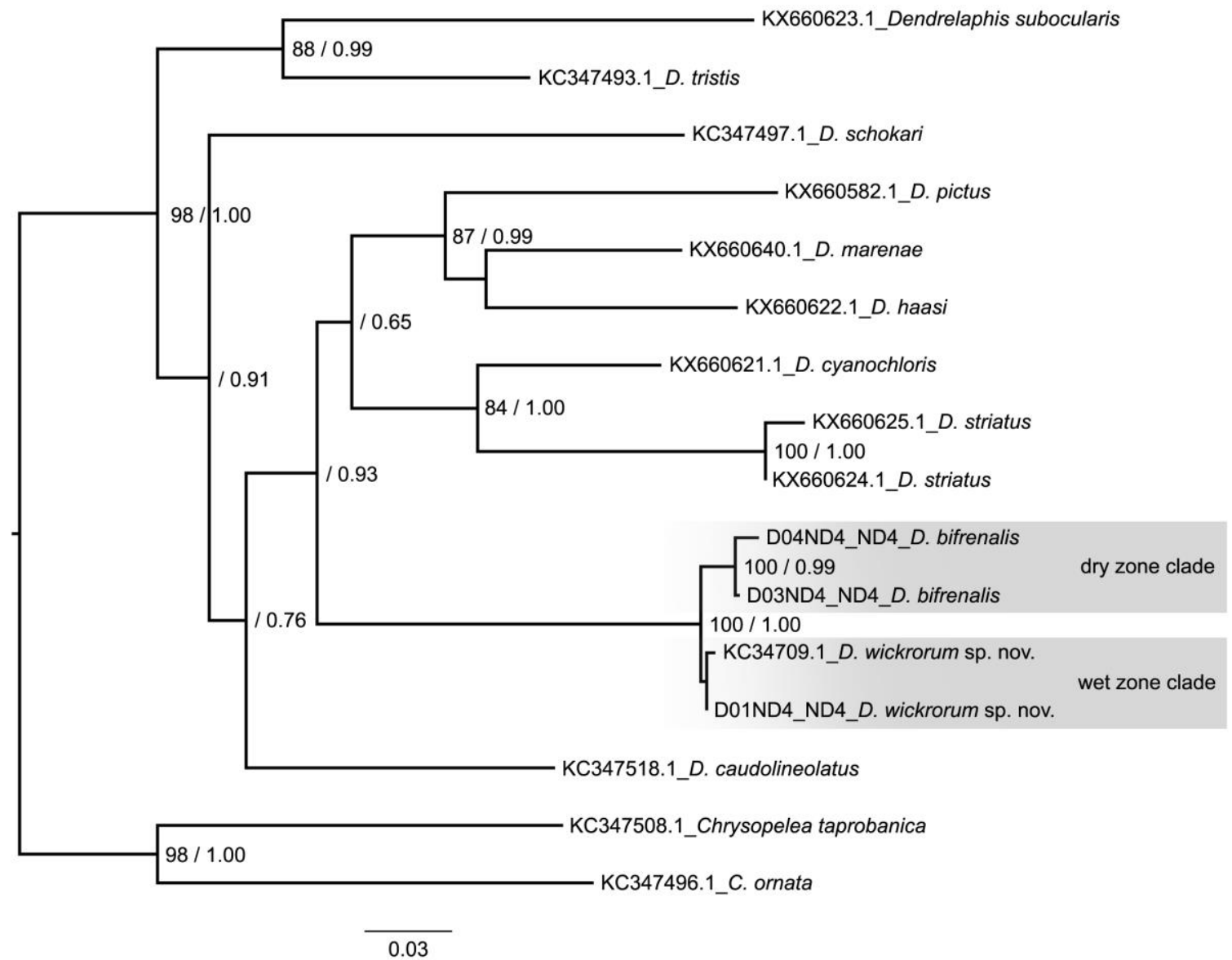

Figure 2. Phylogenetic affinities of D. bifrenalis and D. wickrorum sp. nov. using maximum likelihood (ML) analyses of the mitochondrial ND4 region. The topology of ML and Bayesian analyses were similar. Values on top of the node indicate ML bootstrap support $>80 \%$ and Bayesian posterior probabilities $>0.80$ respectively. 
Table 3. Estimates of similarity values and pairwise evolutionary distances of the members of Dendrelaphis and Chrysopelea. See Table 2 for details of the studied samples.

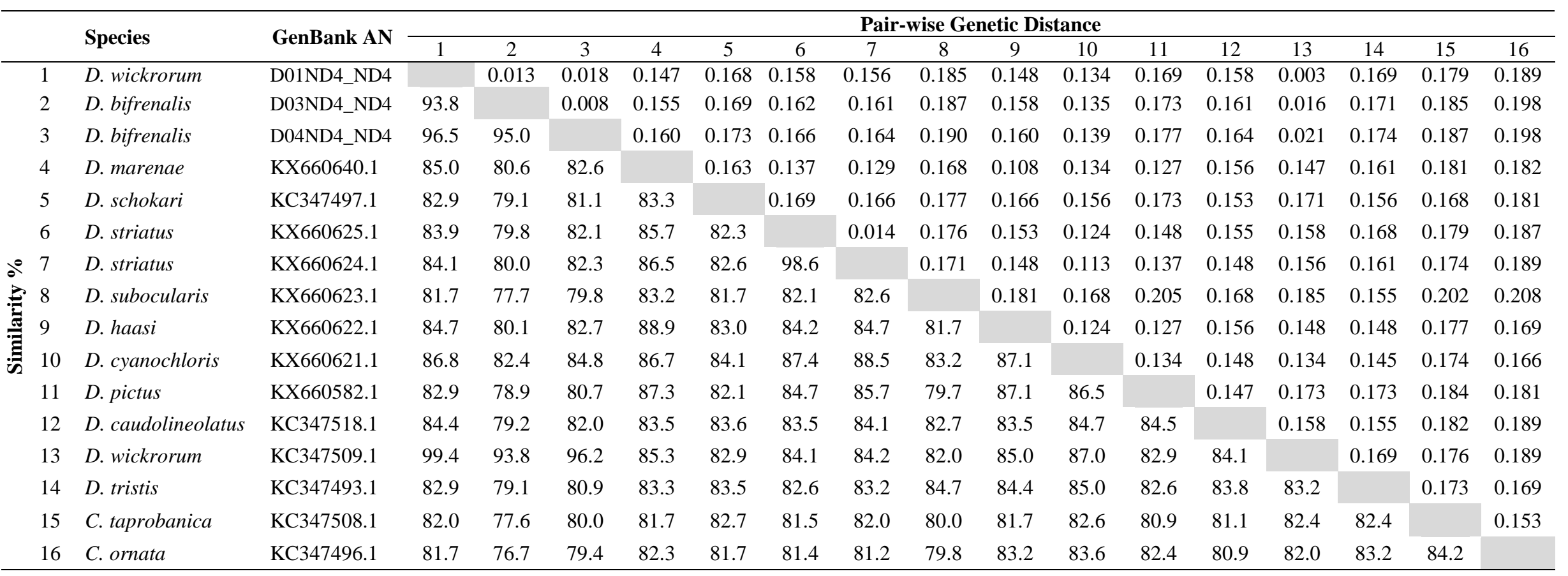




\section{Taxonomy}

In the original description of Dendrophis bifrenalis, Boulenger (1890: 80) clearly mentioned his description was based on three specimens (hence syntypes), and provided meristic characters as a range, except for one measurement. Among the three syntypes, we noticed that there are two morphospecies (mentioned as $\mathrm{A}$ and $\mathrm{B}$ in Table 4), after a critical comparison of the types, other museum specimens, and live specimens we were convinced that the latter (morph B) is morphologically distinct enough to be regarded as a separate species. Therefore, in order to stabilize the name with a recognized type specimen and to solve the taxonomical problem, we designate the specimen measured (intentionally used to write the description) by Boulenger (1890), BMNH 1946.1.6.4 as the lectotype of Dendrophis bifrenalis.

Table 4. Specimen composition of the syntypes of Dendrophis bifrenalis: based on the type series as recorded at BMNH, and as identified by Günther (1858), Boulenger $(1890,1894)$, and personal examination.

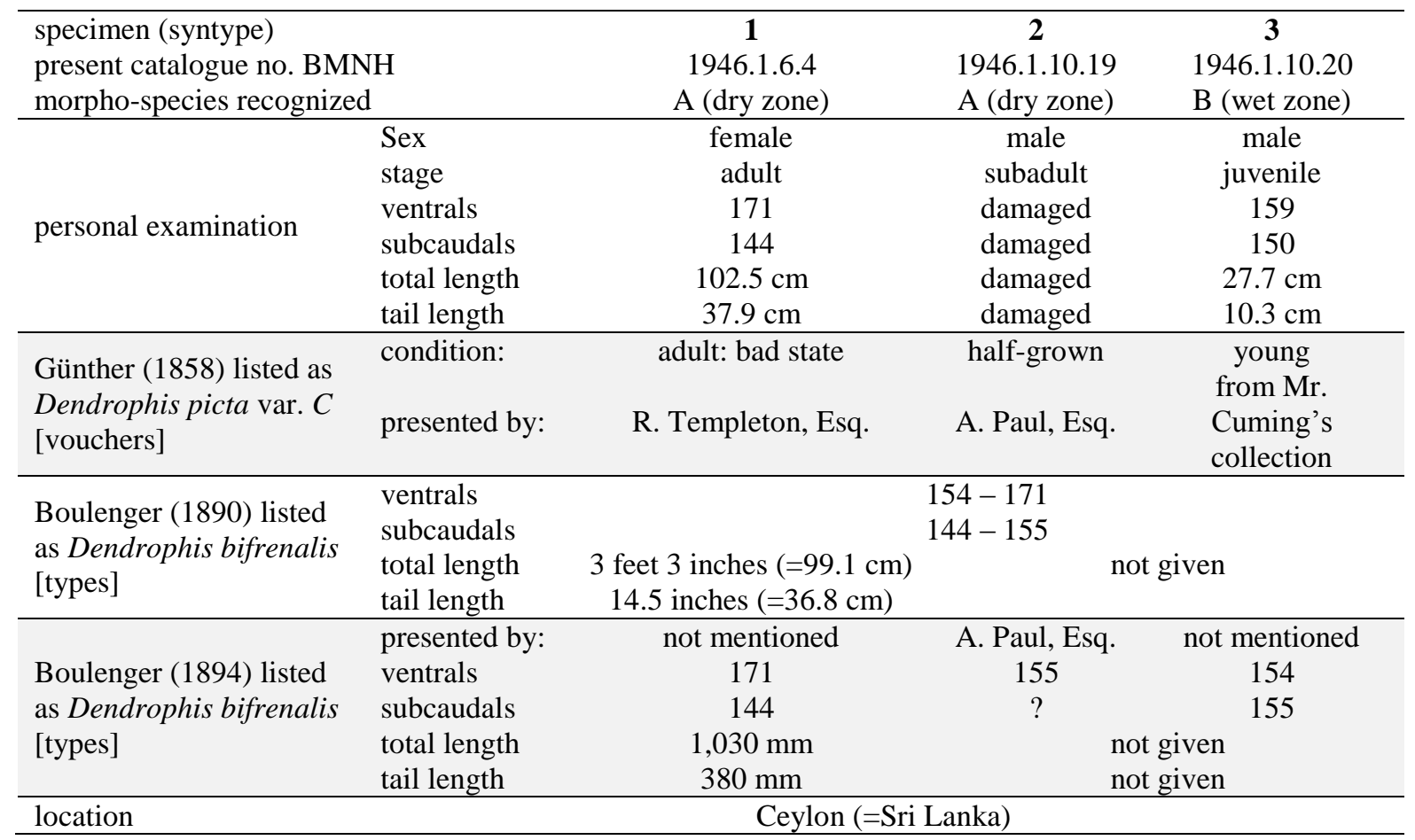

Dendrelaphis bifrenalis (Boulenger, 1890)

(Figs. 1-5, 8, 9B, 10; Tables 1-4, 6, 7)

Dendrophis bifrenalis Boulenger, 1890

Lectotype (designated herein). Adult female, BMNH 1946.1.6.4, SVL $646.0 \mathrm{~mm}$, collected from Ceylon (=Sri Lanka), by A. Paul (fide Boulenger 1894) [presented by R. Templeton (fide Günther 1858), see discussion]

Other specimens $(\boldsymbol{n}=12) . \quad \mathrm{BMNH}$ 1946.1.10.19, damaged, collected from Ceylon, by A. Paul (paralectotype); see Appendix I for other specimen data; Tables 5, 6 for morphometric and meristic data.

Description of lectotype. Adult female (BMNH 1946.1.6.4), SVL $646.0 \mathrm{~mm}$; tail length 379.0 $\mathrm{mm}$; head elongate (HL $3.8 \%$ of SVL), twice as long as wide (HW $42.5 \%$ of HL), slightly flattened, distinct from neck; snout elongate (ES $27.5 \%$ of HL), moderate, blunt in dorsal view, pointed in lateral profile, forming an oval shape, rather depressed.

Rostral shield large, hemispherical, distinctly visible from above, pointed posteriorly; interorbital width broad (IO $78.1 \%$ of HW); internasals pentagonal; nostrils rather large; nasal undivided, elongate, in anterior contact with rostral and internasal dorsally, $1^{\text {st }}$ and $2^{\text {nd }}$ supralabials ventrally, anterior loreal posteriorly; prefrontal rather large, broader than long, and subpentagonal; frontal large, subpentagonal, shorten posteriorly, and length more or less equal to width; supraoculars wide, elongated, posteriorly wider and rounded; parietals large, butterfly wing-like in shape, shorten, rounded posteriorly, bordered by frontal, supraoculars, upper postocular 
anteriorly, anterior and upper posterior temporals, and five dorso-nuchal scales posteriorly; two loreal scales; anterior loreal broader and larger than posterior loreal, in contact with internasal and prefrontal dorsally, and $2^{\text {nd }} \& 3^{\text {rd }}$ supralabials ventrally; posterior loreal narrow and more elongate than anterior loreal, in contact with prefrontal and preocular dorsally and $3^{\text {rd }} \& 4^{\text {th }}$ supralabials ventrally; one preocular (both sides), vertically elongated, pentagonal, in contact with prefrontal and posterior loreal anteriorly, supraocular and frontal (slightly in contact) dorsally, and $4^{\text {th }} \&$ $5^{\text {th }}$ supralabials ventrally; eye large (ED $16.6 \%$ of HL), round, shorter than eye-nostril length (ED $77.3 \%$ of EN, ED $60.3 \%$ of ES), pupil rounded; two postoculars, upper postocular larger, quadrangular, in contact with supraocular and parietal broad, in narrow contact with lower postocular and upper anterior temporal; lower postocular crescent in contact with $6^{\text {th }}$ supralabial ventrally, anterior temporal posteriorly; temporals $2+2+2$; anterior and posterior temporals elongated, hexagonal; anterior temporals smaller than posterior temporals, in contact with parietal dorsally, $7^{\text {th }}$ \& $8^{\text {th }}$ supralabials ventrally; posterior temporals in contact with parietal dorsally, $8^{\text {th }} \& 9^{\text {th }}$ supralabials ventrally.

Supralabials 9 (on both sides), $5^{\text {th }}-9^{\text {th }}$ larger in size, $6^{\text {th }}-9^{\text {th }}$ being the largest; $1^{\text {st }}$ supralabial in contact with rostral anteriorly, nasal dorsally, $2^{\text {nd }}$ supralabial with nasal and anterior loreal dorsally, $3^{\text {rd }}$ supralabial with anterior and posterior loreals dorsally, $4^{\text {th }}$ supralabial with posterior loreal and preocular dorsally, $5^{\text {th }}$ supralabial with preocular and orbit dorsally, $6^{\text {th }}$ supralabial with orbit and the lower postocular dorsally, $7^{\text {th }}$ supralabial with upper \& lower anterior temporals dorsally, $8^{\text {th }}$ supralabial with lower anterior and posterior temporals dorsally, and $9^{\text {th }}$ supralabial with lower posterior temporals dorsally and body scales posteriorly.

Mental of moderate size, triangular, wider than length; first infralabial pair larger than mental plate and in broad contact with each other, in contact with anterior chin shield posteriorly; eleven infralabials, $1^{\text {st }}-6^{\text {th }}$ in contact with anterior chin shield, $6^{\text {th }}$ infralabial in narrow contact with posterior chin shield, $7^{\text {th }}$ infralabial in contact with posterior chin shield and gular scales; two anterior chin shields in broad contact, and two posterior chin shields in narrow contact; posterior chin shields slightly longer than anterior chin shields; posterior chin shields bordered posteriorly by eight gular scales.

Body robust, elongate and subcylindrical; costals in 15-15-11 rows, all smooth and bluntly pointed; 171 ventrals; anal plate divided. Tail comparatively long (TL $58.7 \%$ of SVL), robust and thick, 144 paired subcaudals.

Variation. See Table 6.

Colouration. Over 160 years in preservative (Fig. 3), dorsally dark bluish black; a white colour longitudinal ventro-lateral line starts from anterior body up to the level of vent; dorsal head blue; black transverse ventro-lateral cross bars on the anterior part of the body; a black band (two-scale wide) from posterior nasal across the eye beyond the neck, afterwards connect with black transverse ventro-lateral cross bars (bands); ventral side creamy yellow.

In life (based on Figures 5, 8, 9B and observations), dorsally dark bluish green; a cream colour longitudinal ventro-lateral line starts from anterior body up to the level of vent; dorsal head greenish blue; black transverse ventro-lateral cross bars on the anterior part of the body, in between cross bars luminous blue, brown and gray colour; a black band from posterior nasal across the eye beyond the neck, afterwards connect with black transverse ventrolateral cross bars; vertebral column usually orange or light brown, distinct on the anterior part of the body; ventral side light greenish yellow, throat white.

Dendrelaphis wickrorum sp. nov. (Figs. 1, 2, 6-8, 9A, 10; Tables 1-7)

Holotype. Adult male, BMNH 1905.3.25.98, SVL $368.0 \mathrm{~mm}$, collected from Punduloya, $4,000 \mathrm{ft}$, Ceylon (= Pundaluoya, Sri Lanka, $7^{\circ} 00^{\prime} 47^{\prime \prime} \mathrm{N}, 80^{\circ} 39^{\prime} 47^{\prime \prime} \mathrm{E}$; alt. 1,060 m a.s.1.), Nuwara Eliya District, Central Province, Sri Lanka. Collector and the date unknown.

Paratypes $(n=4)$. Adult female, DWC 2020.05.03, SVL $708.0 \mathrm{~mm}$, collected from Pinwatta-Panadura (6 $6^{\circ} 41^{\prime} 23^{\prime \prime}$ N, 79 55'24" E; alt. 15 m a.s.l.), Kalutara District, Western Province, Sri Lanka; Adult male, DWC 2020.05.04, SVL $489.0 \mathrm{~mm}$, collected from Kuda-Waskaduwa $\left(6^{\circ} 37^{\prime} 11^{\prime \prime} \mathrm{N}, 79^{\circ} 56^{\prime} 51^{\prime \prime} \mathrm{E}\right.$; alt. $15 \mathrm{~m}$ a.s.1.), Kalutara District, Western Province, Sri Lanka, by L.J.M. Wickramasinghe on 20 October 2006; Subadult male, USNM 267765, SVL $285.0 \mathrm{~mm}$, collected from Labugama (6 $50^{\prime} 49^{\prime \prime} \mathrm{N}, 80^{\circ} 11^{\prime} 35^{\prime \prime}$ E; alt. 140 m a.s.1.), Colombo District, Western Province, Sri Lanka, by A. de Silva, on 


\section{Plate 30}
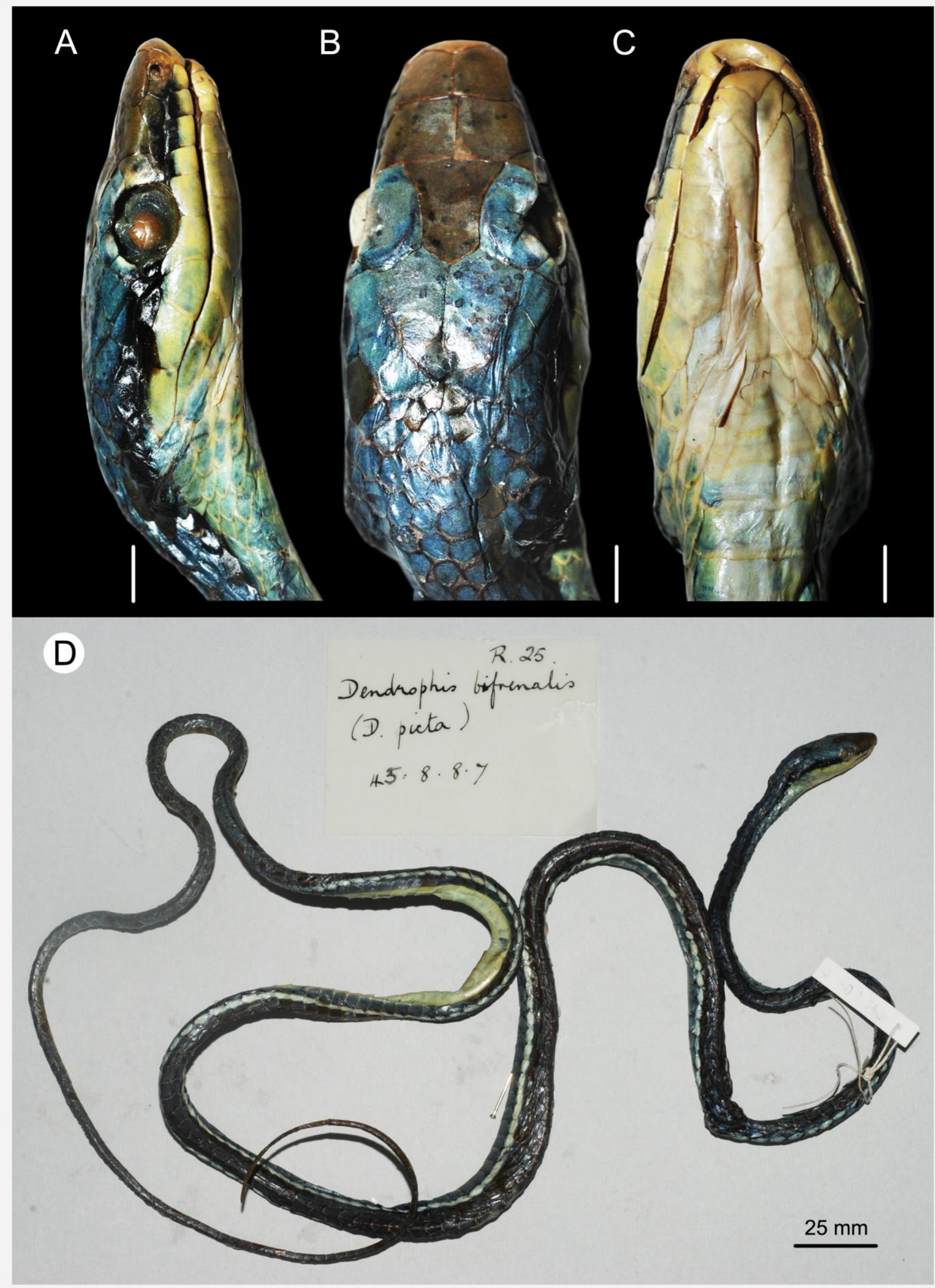

Figure 3. Dendrelaphis bifrenalis lectotype, female (BMNH 1946.1.6.4) from Ceylon [=Sri Lanka, probably from dry zone of Sri Lanka]; head in (A) lateral view, (B) dorsal view, (C) ventral view (scale: $3 \mathrm{~mm}$ ); and (D) the full body of the lectotype (SVL $646.0 \mathrm{~mm}$ ). 


\section{Plate 31}

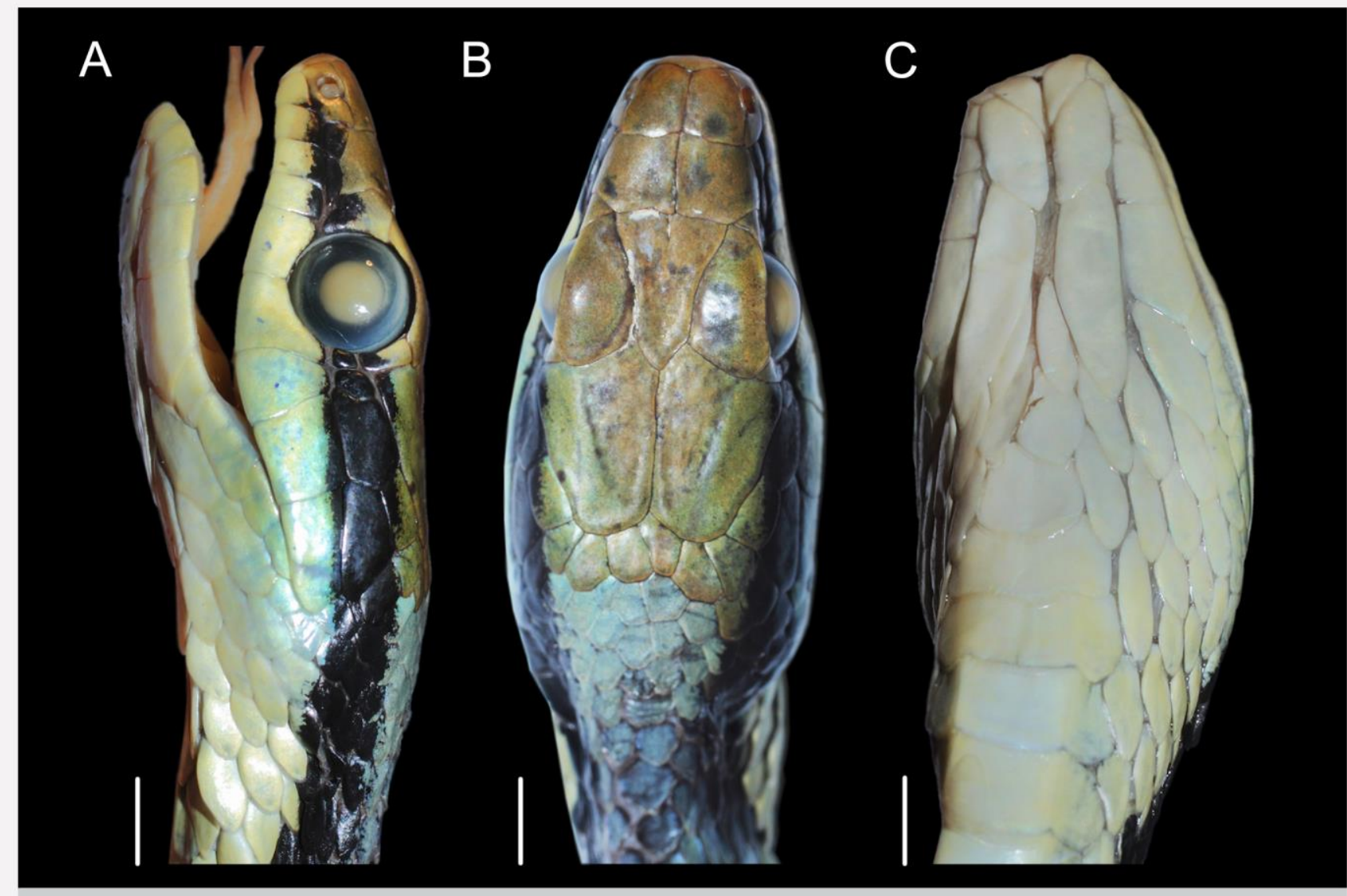

D

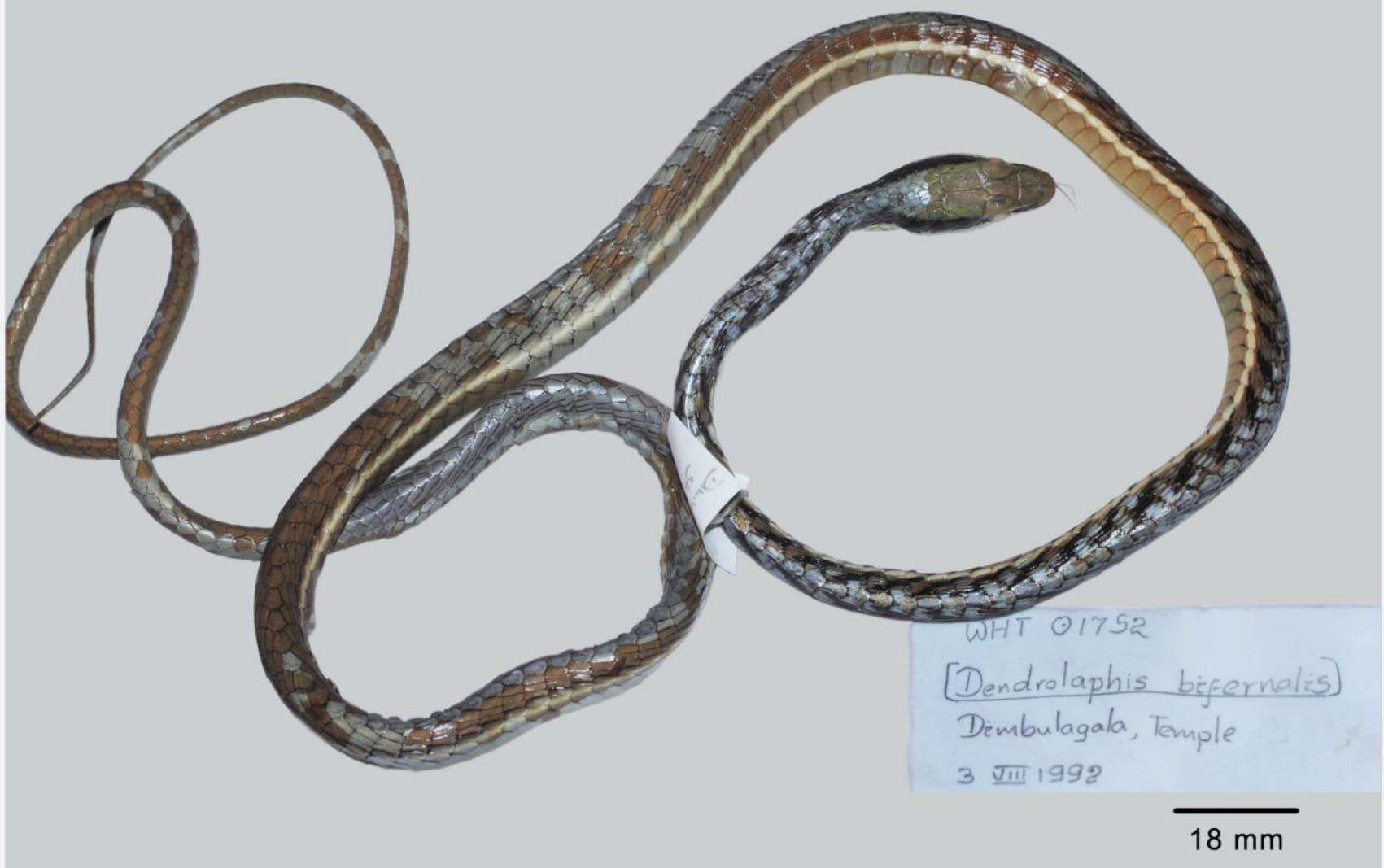

Figure 4. Dendrelaphis bifrenalis adult male (WHT 1752A) from Dimbulagala Temple, Polonnaruwa District, dry zone of Sri Lanka; head in (A) lateral view, (B) dorsal view, (C) ventral view (scale: $3 \mathrm{~mm}$ ); and (D) the full body of the specimen (SVL $620.0 \mathrm{~mm}$ ). 


\section{Plate 32}
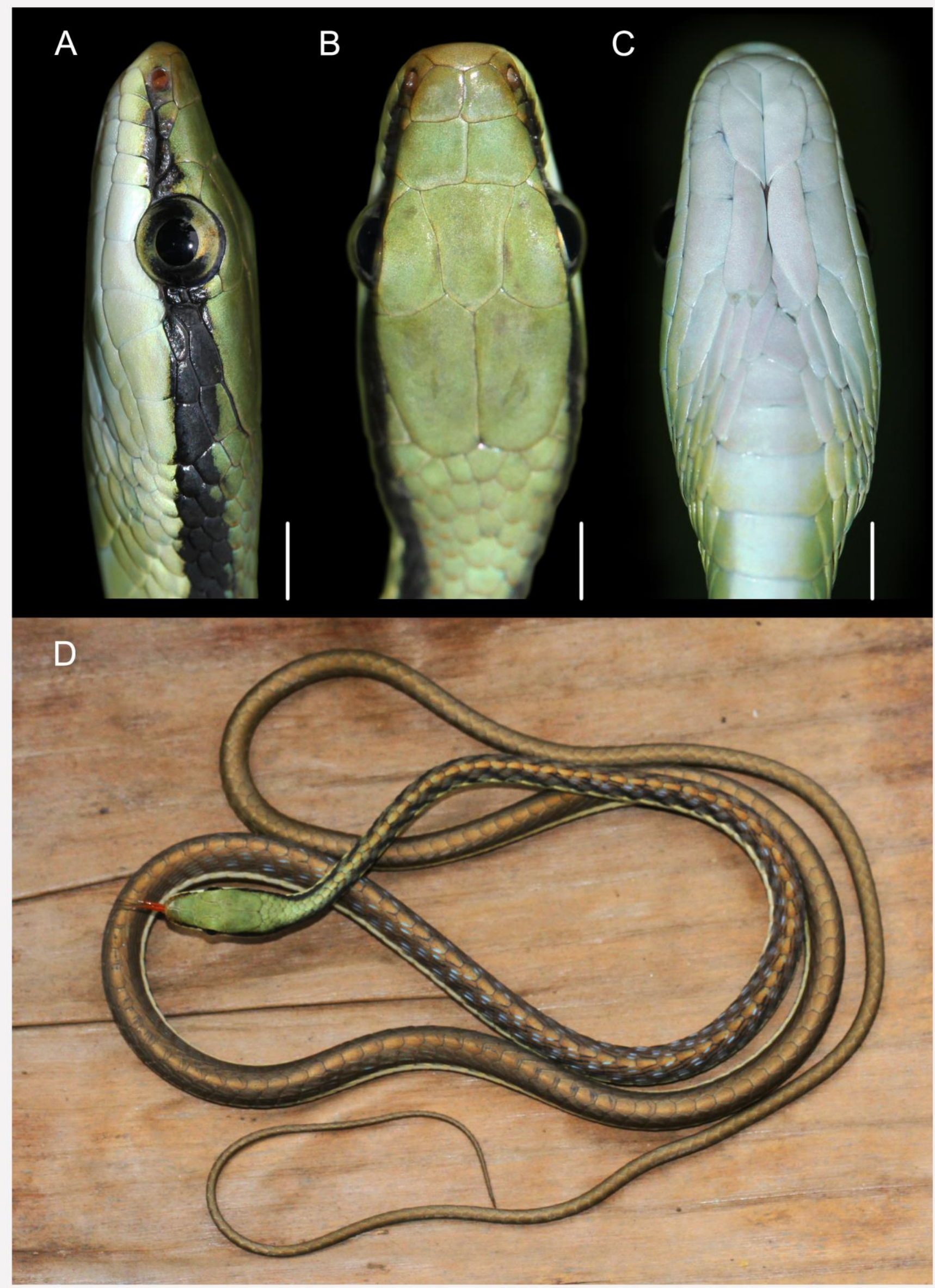

Figure 5. A subadult male of Dendrelaphis bifrenalis (not collected) from Wahalkada, near Padaviya, North Central Province, Sri Lanka; head in (A) lateral view, (B) dorsal view, (C) ventral view (scale: $2 \mathrm{~mm}$ ); and (D) the full body of the individual (SVL, $470.0 \mathrm{~mm}$ ). 
December 1976; Juvenile male, BMNH 1946.1.10.20, SVL $174.0 \mathrm{~mm}$, collected from Ceylon, by Mr. Hugh Cuming (paralectotype of $D$. bifrenalis), collecting data unknown; see Tables 4 for morphometric and meristic characters.

Diagnosis. The following combination of characters distinguishes the new species from Dendrelaphis bifrenalis: shorter snout: ED 103$114 \%$ of EN ( $v s 77-95 \%$ ), larger eye: ED 21$23 \%$ of HL ( $v s 17-20 \%$ ), presence of a temporal stripe stopping just beyond the neck (vs continues behind neck), absence of black transverse dorsolateral bars on the anterior $1 / 4^{\text {th }}$ of body ( $v s$ prominent), presence of a ventrolateral stripe continuing up to the tail ( $v s$ stopping at the level of anal plate) and narrow and pointed snout ( $v s$ broad and flat). Furthermore a divided nasal ( $v s$ single) distinguishes the new species; the differences are shown in Figs. $8 \&$ 9, and summarized in Tables 6 \& 7 .

Description of holotype. Adult male, SVL $368.0 \mathrm{~mm}$; tail length $222.0 \mathrm{~mm}$; head elongate (HL $3.7 \%$ of SVL), twice as long as wide (HW $46.3 \%$ of HL), slightly flattened, distinct from neck; snout elongate (ES 28.7\% of HL), moderate, rounded in dorsal and lateral profiles, forming an oval shape, rather depressed.

Rostral shield large, hemispherical, distinctly visible from above, concave posteriorly; interorbital width broad (IO $73.0 \%$ of HW); internasals pentagonal; nostrils rather large; nasal divided, elongate, in anterior contact with rostral and internasal dorsally, $1^{\text {st }}$ and $2^{\text {nd }}$ supralabials ventrally, anterior loreal and prefrontal (slightly touched) posteriorly; prefrontal rather large, broader than long, and subpentagonal; frontal large, subpentagonal, elongate posteriorly and longer than its width; supraoculars wide, elongated, subrectangular, posteriorly wider and pointed; parietals large, butterfly wing-like in shape, elongated, bordered by frontal, supraoculars, upper postocular anteriorly, anterior and posterior temporals, and six dorso-nuchal scales posteriorly; two loreal scales; anterior loreal smaller than posterior loreal, in contact with prefrontal dorsally and $2^{\text {nd }}$ $\& 3^{\text {rd }}$ supralabial ventrally; posterior loreal broad and more elongate than anterior loreal, in contact with prefrontal and preocular dorsally and $3^{\text {rd }}-5^{\text {th }}$ supralabials ventrally; one preocular (both sides), vertically elongated, pentagonal, in contact with prefrontal and posterior loreal anteriorly, supraocular dorsally, and $5^{\text {th }}$ supralabial ventrally; eye large (ED 23.5\% of $\mathrm{HL}$ ), oval, greater than eye-nostril length (ED $114.3 \%$ of EN, ED $82.0 \%$ of ES), pupil rounded; two postoculars, upper postocular larger, quadrangular, vertically elongated, in contact with supraocular, parietal and anterior temporal broadly; lower postocular crescent in contact with $7^{\text {th }}$ supralabial ventrally, anterior temporal posteriorly; temporals $1+1+2$, anterior temporal shorten, posterior temporals elongated, hexagonal; anterior temporal in contact with parietal dorsally, $8^{\text {th }} \& 9^{\text {th }}$ supralabials ventrally; posterior temporals larger and similar in size, in contact with parietal dorsally, $9^{\text {th }}-10^{\text {th }}$ supralabials ventrally.

Supralabials 10 ( 9 on left sides), $6^{\text {th }}-10^{\text {th }}$ larger in size, $9^{\text {th }}$ being the largest; $1^{\text {st }}$ supralabial in contact with rostral anteriorly, nasals dorsally, $2^{\text {nd }}$ supralabial with posterior nasal and anterior loreal dorsally, $3^{\text {rd }}$ supralabial with anterior and posterior loreals dorsally, $4^{\text {th }}$ supralabial with posterior loreal dorsally, $5^{\text {th }}$ supralabial with posterior loreal and preocular dorsally, $6^{\text {th }}$ supralabial with orbit dorsally, $7^{\text {th }}$ supralabial with orbit and the lower postocular dorsally, $8^{\text {th }}$ supralabial with anterior temporal dorsally, $9^{\text {th }}$ supralabial with anterior and posterior temporals dorsally, and $10^{\text {th }}$ supralabial with posterior temporals dorsally and body scales posteriorly.

Mental of moderate size, triangular, wider than long; first infralabial pair larger than mental plate and in broad contact with each other, in contact with anterior chin shield posteriorly; ten infralabials, $1^{\text {st }}-5^{\text {th }}$ in contact with first chin shield, $5^{\text {th }}$ infralabial in broad contact with posterior chin shield, $6^{\text {th }}$ infralabial in contact with posterior chin shield and gular scales; two smaller anterior chin shields in broad contact, and two elongated posterior chin shields in broad contact; posterior chin shields bordered posteriorly by eight gular scales.

Body robust, elongate and subcylindrical; costals in 15-15-9 rows, smooth and bluntly pointed, anterior costals with a single apical pit at the tip; 162 ventrals; anal plate divided. Tail comparatively long (TL $60.3 \%$ of SVL), robust and thick, 150 paired subcaudals.

Variation. See Table 5.

Colouration. In preservative (Fig. 6), dorsally brownish green; a yellow colour longitudinal ventro-lateral line starts from anterior body continues until tail; dorsal head pale grayish green; a black stripe (one scale 
wide) from posterior nasal across the eye until the neck, disappeared afterwards; some faint ventro-lateral cross stripes are visible [not prominent as in $D$. bifrenalis, which are cross bands]; ventral side brownish yellow.

In life (Figs. 7, 8, 9A), dorsally olive green; a yellow colour longitudinal ventro-lateral line starts from anterior body continues until tail; dorsal head dark olive green; a black stripe (mostly one scale wide) from posterior nasal across eye until the neck, disappeared afterwards; rarely ventro-lateral cross stripes are visible, but never prominent as in $D$. bifrenalis; ventral side creamy yellow.

Etymology. The specific epithet is a noun in the genitive case, honoring Mr. L.J. Mendis Wickramasinghe and his wife Mrs. Nethu Wickramasinghe for their remarkable contributions to the field of herpetology in Sri Lanka. Especially, Mendis Wickramasinghe's enormous effort in popularizing snake conservation among the general public is highly commendable. We shorten their modern name to the stem "Wickr" and formed in case of plural adding the suffix [-orum].

Suggested vernacular names are

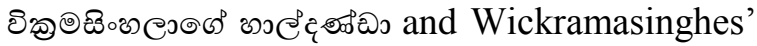

Bronze-back in Sinhala and English respectively.

Comparison. Dendrelaphis wickrorum sp. nov. is most similar to D. bifrenalis (in Sri Lanka) and D. girii Vogel \& van Rooijen, 2011b (in India), the diagnostic characters are listed in the diagnosis and Table 6. The new species is distinguished from all the Sri Lankan and Indian Dendrelaphis by having two loreal scales ( $v s$ absent or single), except for D. bifrenalis (see Table 7). It further differs from $D$. caudolineolatus by having 9 or 10 supralabials $5^{\text {th }}-6^{\text {th }}$ or $6^{\text {th }}-7^{\text {th }}$ touching the eye (vs 8 and $4^{\text {th }}-$ $5^{\text {th }}$ touching the eye), costals in 15 rows at mid body ( $v s$ 13), 157-162 ventrals ( $v s$ 149); from $D$. sinharajensis by having temporal stripe and ventrolateral stripe ( $v s$ absent), 9 or 10 supralabials ( $v s 8$ ), costals in 15 rows at mid body (vs 13), 157-162 ventrals ( $v s$ 174); from $D$. oliveri by having $5^{\text {th }}-6^{\text {th }}$ or $6^{\text {th }}-7^{\text {th }}$ supralabials touching the eye ( $\left.v s 4^{\text {th }}-6^{\text {th }}\right), 157-162$ ventrals (vs 173), 150-157 subcaudals (vs 134), temporal stripe stops beyond the neck ( $v s$ until tail base); from $D$. schokari by having $150-157$ subcaudals (vs 105-127); and from D. tristis by having 157-162 ventrals (vs 178-198), no interparietal bright spot ( $v s$ present).

Table 5. Selected Morphometric (in mm), meristric, and morphological characters of the holotype and paratypes of Dendrelaphis wickrorum sp. nov.; "_-" = not measured.

\begin{tabular}{|c|c|c|c|c|c|}
\hline \multirow{5}{*}{ Character } & \multicolumn{4}{|c|}{ D. wickrorum sp. nov. } & \multirow{5}{*}{$\begin{array}{c}\text { female } \\
\text { paratype } \\
\text { DWC } \\
2020.05 .03\end{array}$} \\
\hline & \multicolumn{4}{|c|}{ males } & \\
\hline & holotype & paratype & paratype & paratype & \\
\hline & BMNH & BMNH & USNM & DWC & \\
\hline & 1905.3.25.98 & 1946.1.10.20 & 267765 & 2020.05 .04 & \\
\hline snout-vent length (SVL) & 368.0 & 172.0 & 285.0 & 489.0 & 708.0 \\
\hline tail length (TL) & 222.0 & 104.0 & 179.0 & 298.0 & 396.0 \\
\hline relative TL (TL/SVL)\% & $60.33 \%$ & $60.46 \%$ & $62.80 \%$ & $60.94 \%$ & $60.0 \%$ \\
\hline head length (HL) & 13.65 & 11.24 & 12.40 & 18.04 & 23.45 \\
\hline head width (HW) & 6.34 & 4.84 & - & 7.28 & 11.36 \\
\hline internarial distance (IN) & 2.39 & 2.05 & - & 3.09 & 3.93 \\
\hline interorbital width (IO) & 4.57 & 4.11 & - & 6.07 & 7.56 \\
\hline eye-nostril length (EN) & 2.80 & 2.34 & 2.61 & 3.77 & 4.94 \\
\hline eye-snout length (ES) & 3.92 & 2.55 & - & 5.71 & 7.75 \\
\hline eye diameter (ED) & 3.20 & 2.41 & 2.69 & 3.91 & 5.00 \\
\hline relative $\mathrm{ED} / \mathrm{EN} \%$ & $114.28 \%$ & $102.99 \%$ & 103.06 & $103.71 \%$ & $101.21 \%$ \\
\hline relative ED/HL\% & $23.44 \%$ & $21.44 \%$ & $21.69 \%$ & $21.67 \%$ & $21.32 \%$ \\
\hline costals & $15-15-9$ & $15-15-9$ & $15-15-9$ & $15-15-10$ & $15-15-11$ \\
\hline ventrals & 162 & 162 & 163 & 174 & 167 \\
\hline subcaudals & 150 & 154 & 157 & 154 & 137 \\
\hline supralabials (SUP) & 10 & 9 & 9 & 9 & 9 \\
\hline SUP at mid orbit position & 6,7 & 5,6 & 5,6 & 5,6 & 5,6 \\
\hline infralabials & 11 & 10 & 10 & 10 & 12 \\
\hline Location & Pundaluoya & unknown & Labugama & Waskaduwa & Pinwatta \\
\hline
\end{tabular}




\section{Plate 33}
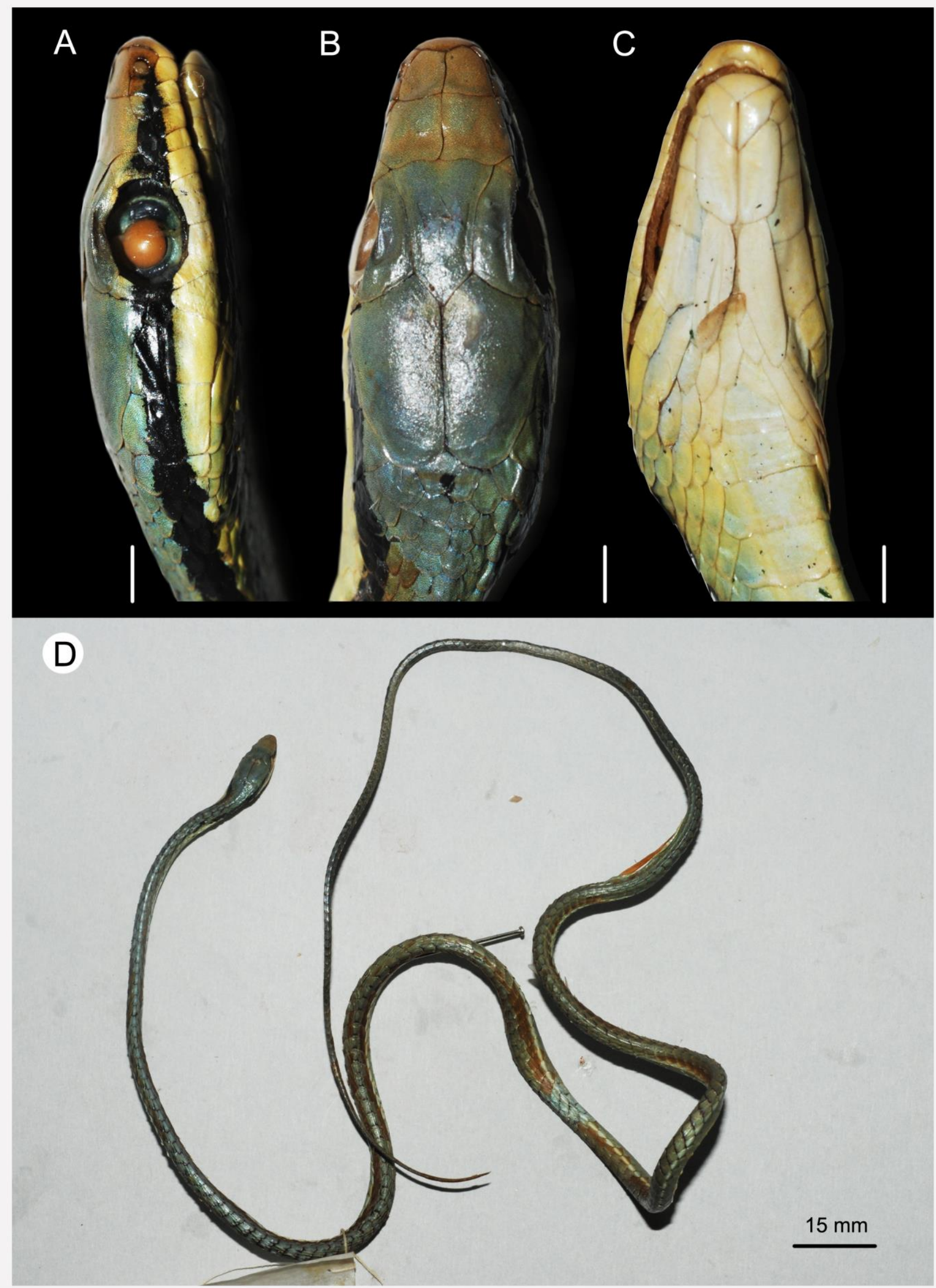

Figure 6. Dendrelaphis wickrorum sp. nov., an adult male, holotype (BMNH 1905.3.25.98) from Pundaluoya, Central Province, Sri Lanka (submontane wet zone); head in (A) lateral view, (B) dorsal view, (C) ventral view (Scale: $1.5 \mathrm{~mm}$ ); and (D) the full body of the specimen (SVL $368.0 \mathrm{~mm}$ ). 


\section{Plate 34}

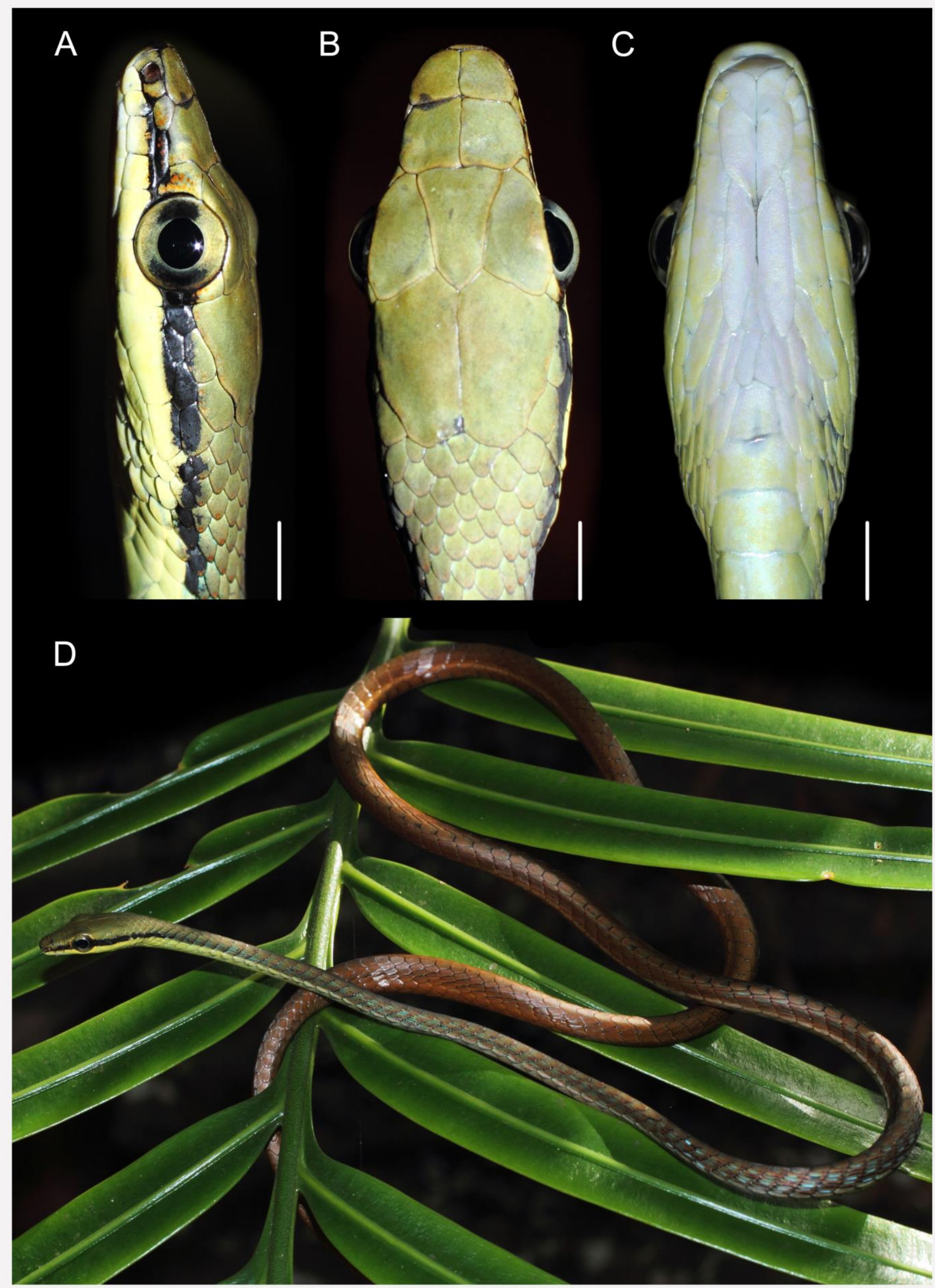

Figure 7. An adult male of Dendrelaphis wickrorum sp. nov. (not collected) from Athwalthota forest, Matugama, Kalutara District, Sri Lanka; head in (A) lateral view, (B) dorsal view, (C) ventral view (scale: $2 \mathrm{~mm}$ ); and (D) the full body of the individual (SVL, $350.0 \mathrm{~mm}$ ). 

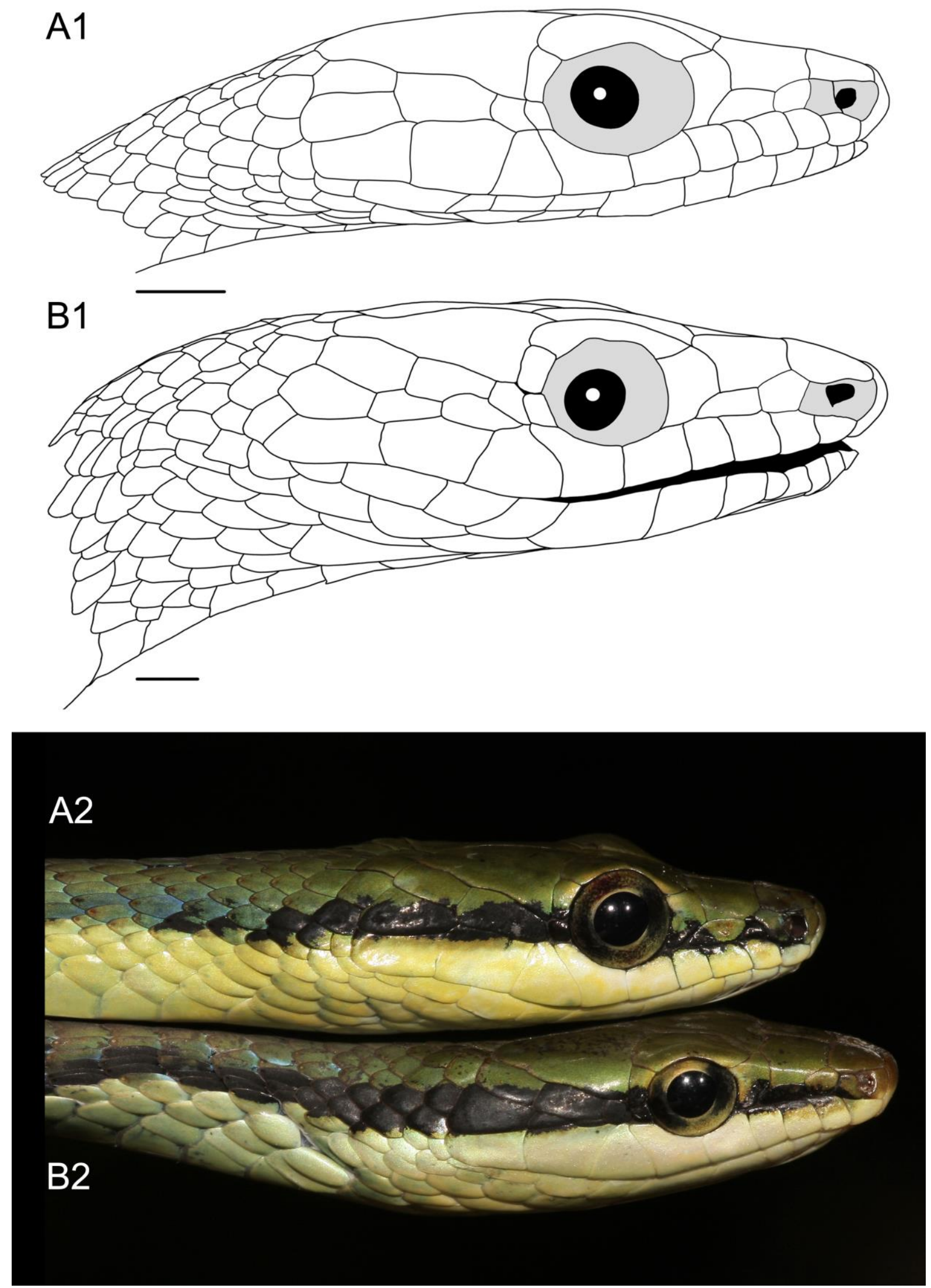

Figure 8. Head in lateral view (A1) holotype male of Dendrelaphis wickrorum sp. nov. (BMNH 1905.3.25.98) from Pundaluoya (wet zone) and (B1) lectotype female of D. bifrenalis (BMNH 1946.1.6.4) from dry zone; (A2) paratype female of $D$. wickrorum sp. nov. (DWC 2020.05.03) from Pinwatta (wet zone) and (B2) female D. bifrenalis (DWC 2020.05.06) from Girithale (dry zone); scale: $2 \mathrm{~mm}$. Illustration and Photo (C) L.J.M. Wickramasinghe. 
Table 6. Selected Morphometric (in mm), meristric, and morphological characters of the species of the Dendrelaphis bifrenalis complex including data of onomatophores; " - " = not measured.

\begin{tabular}{|c|c|c|c|c|c|c|}
\hline \multirow[b]{2}{*}{ Character } & \multicolumn{2}{|c|}{ D. bifrenalis } & \multicolumn{2}{|c|}{ D. girii } & \multicolumn{2}{|c|}{ D. wickrorum sp. nov. } \\
\hline & $\begin{array}{l}\text { males } \\
(n=6)\end{array}$ & $\begin{array}{c}\text { females } \\
(n=8)\end{array}$ & $\begin{array}{l}\text { male } \\
(n=1)\end{array}$ & $\begin{array}{c}\text { females } \\
(n=4)\end{array}$ & $\begin{array}{l}\text { males } \\
(n=4)\end{array}$ & $\begin{array}{c}\text { female } \\
(n=1)\end{array}$ \\
\hline snout-vent length & $379-620$ & $344-646$ & 653.0 & $465-743$ & $173-489$ & 708 \\
\hline tail length (TL) & $261-370$ & $201-395$ & 373.0 & $271-334$ & $103-298$ & 396 \\
\hline relative TL of SVL & $0.58-0.64$ & $0.58-0.61$ & 0.57 & $0.58-0.59$ & $0.60-0.63$ & 0.60 \\
\hline head length (HL) & $15.6-24.3$ & $14.1-27.4$ & 23.1 & $17.6-26.3$ & $11.2-18.0$ & 23.4 \\
\hline head width & $6.5-8.9$ & $9.2-11.4$ & - & - & $4.8-7.3$ & 11.4 \\
\hline eye-nostril length (EN) & $3.1-5.0$ & $3.1-5.9$ & 5.0 & $3.8-6.1$ & $2.3-3.8$ & 4.9 \\
\hline eye-snout length & $3.9-6.5$ & $4.2-7.7$ & - & - & $2.5-5.7$ & 7.7 \\
\hline eye diameter (ED) & $2.9-4.3$ & $2.8-4.9$ & 4.4 & $3.2-4.9$ & $2.4-3.9$ & 5.0 \\
\hline relative $\mathrm{ED}$ of $\mathrm{EN} \%$ & $86-97 \%$ & $77-95 \%$ & $86 \%$ & $77-95 \%$ & $103-114 \%$ & $101 \%$ \\
\hline relative ED of HL\% & $18-20 \%$ & $17-19 \%$ & $18 \%$ & $17-20 \%$ & $21-23 \%$ & $21 \%$ \\
\hline costals & $15-15-9$ & $15-15-11$ & $15-15-11$ & $15-15-11$ & $15-15-9$ & $15-15-11$ \\
\hline ventrals & $153-173$ & $161-173$ & 169 & $166-173$ & $162-174$ & 167 \\
\hline subcaudals & $140-166$ & $139-154$ & 147 & $140-145$ & $150-157$ & 137 \\
\hline supralabials & 9 & 9 & 9 & 8,9 & 9,10 & 9 \\
\hline infralabials & 10 & 10 & 10 & 9,10 & 10,11 & 12 \\
\hline nasal plate & \multicolumn{2}{|c|}{ undivided } & \multicolumn{2}{|c|}{ divided } & \multicolumn{2}{|c|}{ divided } \\
\hline snout shape & \multicolumn{2}{|c|}{ wide, flat } & \multicolumn{2}{|c|}{ wide, flat } & \multicolumn{2}{|c|}{ narrow, pointed } \\
\hline $\begin{array}{l}\% \text { of temporal region } \\
\text { covered by temporal stripe }\end{array}$ & \multicolumn{2}{|c|}{$60-80 \%$} & \multicolumn{2}{|c|}{$15-25 \%$} & \multicolumn{2}{|c|}{$40-60 \%$} \\
\hline transverse dorsolateral bars & \multicolumn{2}{|c|}{ present } & \multicolumn{2}{|c|}{ absent } & \multicolumn{2}{|c|}{ absent } \\
\hline ventro-lateral line & \multicolumn{2}{|c|}{ up to vent } & \multicolumn{2}{|c|}{ absent } & \multicolumn{2}{|c|}{ up to tail } \\
\hline Distribution & \multicolumn{2}{|c|}{$\begin{array}{l}\text { Mostly in dry zone } \\
\text { Sri Lanka }\end{array}$} & \multicolumn{2}{|c|}{$\begin{array}{l}\text { south and western } \\
\text { parts of India }\end{array}$} & \multicolumn{2}{|c|}{$\begin{array}{l}\text { wet zone } \\
\text { Sri Lanka }\end{array}$} \\
\hline
\end{tabular}

Table 7. Selected diagnostic characters of the Dendrelaphis species occur in Sri Lanka; “__"= not evaluated.

\begin{tabular}{|c|c|c|c|c|c|c|c|}
\hline Character & 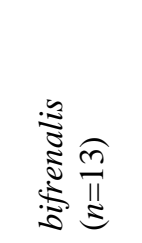 & 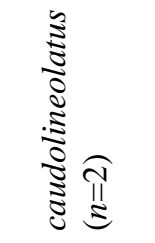 & 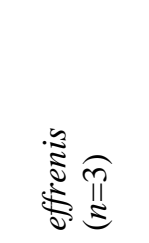 & 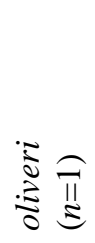 & 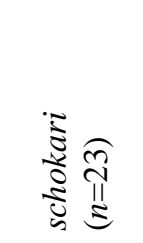 & 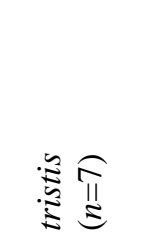 & 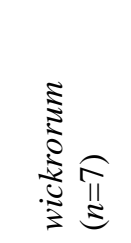 \\
\hline maximum SVL in $\mathrm{mm}$ & 708 & 650 & 672 & 756 & 1,190 & 1,310 & 489 \\
\hline relative (TL/SVL)\% & $58-64$ & 36 & $38-48$ & 33 & $44-56$ & $48-64$ & $60-63$ \\
\hline relative (ED/EN) \% & $86-97$ & 100 & 109 & - & $69-70$ & $65-68$ & $101-114$ \\
\hline loreal absent (0) one (1) two (2) & 2 & 1 & 0 & 0 & 1 & 1 & 2 \\
\hline snout narrow (0), wide (1) & 1 & 1 & 0 & 0 & 0 & 1 & 0 \\
\hline nasal single (1), divided (2) & 1 & 2 & 1 & 2 & 2 & 2 & 2 \\
\hline $\begin{array}{l}\text { interparietal spot absent }(0) \text {, } \\
\text { present (1) }\end{array}$ & 0 & 0 & 0 & 0 & 0 & 1 & 0 \\
\hline $\begin{array}{l}\text { parietal stripe absent }(0) \text {, present } \\
\text { (1) }\end{array}$ & 0 & 0 & 1 & 0 & 0 & 0 & 0 \\
\hline $\begin{array}{l}\text { ventro-lateral line absent }(0) \text {, } \\
\text { upto vent (1), upto tail ( } 2)\end{array}$ & 1 & 0 & 0 & 1 & 2 & 2 & 2 \\
\hline $\begin{array}{l}\text { cross bands on dorsum absent } \\
(0) \text {, present (1) }\end{array}$ & 0 & 1 & 1 & 0 & 0 & 0 & 0 \\
\hline $\begin{array}{l}\text { temporal stripe absent }(0) \text {, } \\
\text { present (1) }\end{array}$ & 1 & 1 & 0 & 1 & 1 & 1 & 1 \\
\hline costals at midbody & 15 & 13 & 13 & 15 & 15 & 15 & 15 \\
\hline ventrals & $153-173$ & $149-164$ & $174-175$ & 173 & $155-177$ & $178-198$ & $162-174$ \\
\hline subcaudals & $137-166$ & $119-128$ & $129-139$ & 134 & $105-127$ & $121-136$ & $150-157$ \\
\hline SUP touching the eye & 5,6 & 4,5 & 4,5 & $4-6$ & 5,6 & 5,6 & 5,6 \\
\hline INF touching chin shields & $1-5$ & $1-4$ & $1-5$ & $1-5$ & - & & $1-5$ \\
\hline temporals & $2+2$ & $1+1,1+2$ & $1+2,2+3$ & $1+1$ & $2+2$ & $2+1$ & $1+1$ \\
\hline anal plate single (1), divided (2) & 2 & 2 & 1 & 2 & 2 & 2 & 2 \\
\hline maxillary teeth & $24-25$ & $29-32$ & - & - & - & - & $24-25$ \\
\hline
\end{tabular}




\section{Plate 35}
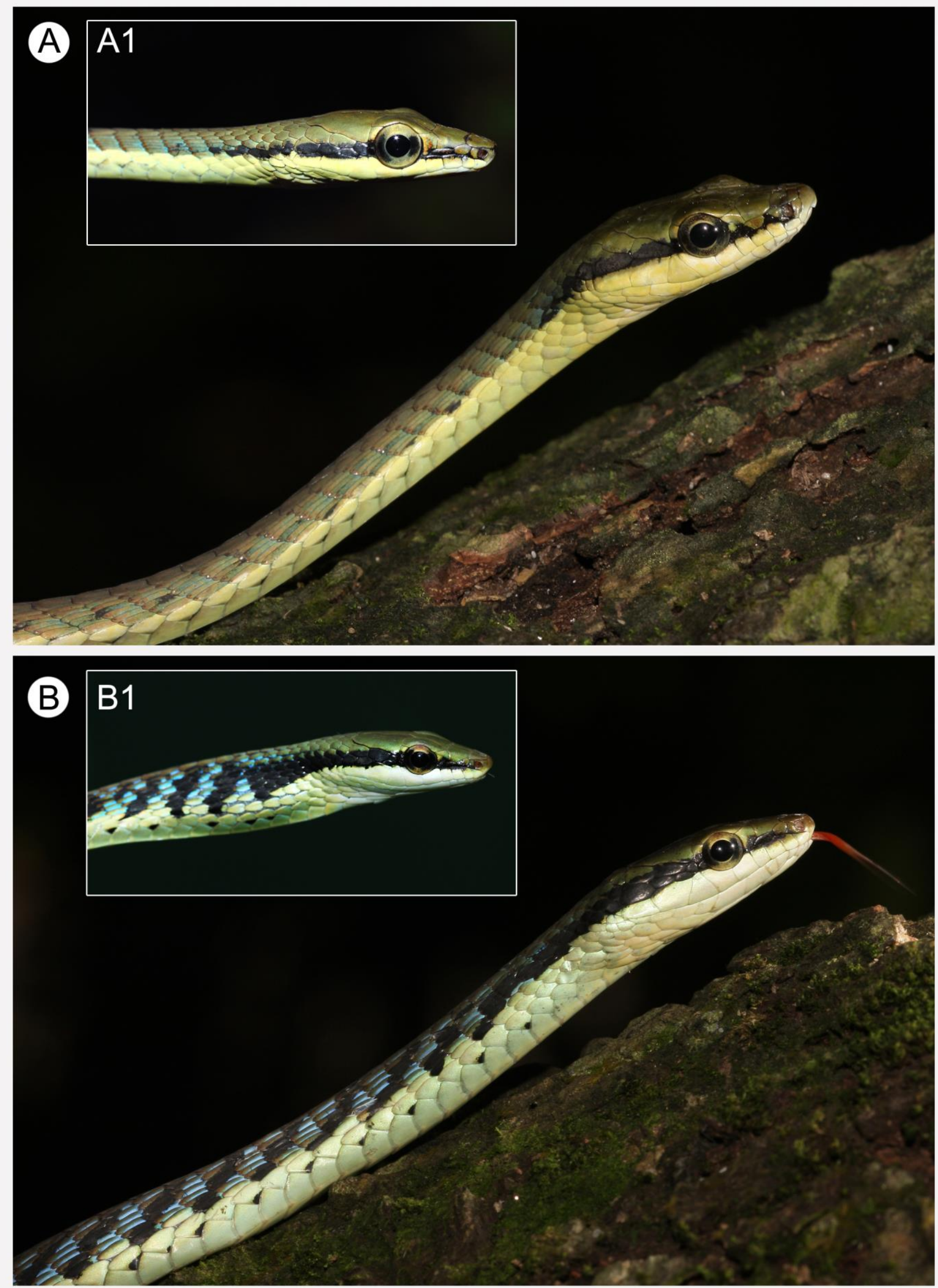

Figure 9. Adult females of (A) Dendrelaphis wickrorum sp. nov. (paratype, DWC 2020.05.03, SVL 708.0 mm) collected from Pinwatta - Panadura (wet zone); and (B) D. bifrenalis (DWC 2020.05.06, SVL $602.0 \mathrm{~mm}$ ) collected from Girithale (dry zone) in Sri Lanka. Photo (C L.J.M. Wickramasinghe. (A1, B1) different individuals, not collected. 


\section{Discussion}

In his book of "The Catalogue of Colubrine Snakes", Günther (1858: 148) listed three specimens of Dendrophis picta var $C$ from Ceylon (=Sri Lanka), see Table 4. Ferguson (1877: 20) too mentioned possibly the same three specimens as Dendrophis picta var $C$. Neither Boulenger (1890) nor any other author provided precise locality data for the syntypes of Dendrelaphis bifrenalis, except to say they came from Ceylon (=Sri Lanka). According to Günther (1858) the largest syntype was presented by R. Templeton but the collector was not mentioned, so therefore remains untraceable.

Robert Templeton (1802-1892), a naturalist, artist, and entomologist, worked in Sri Lanka as a surgeon in the Royal Artillery of the British Army from 1839 to 1851 , until he was recalled in 1852 due to the Crimean War (Nash et al. 1980, Pethiyagoda 2007, Beolens et al. 2011). During a twelve-year stay in Sri Lanka, Templeton worked mainly on Lepidoptera, Coleoptera and Hymenoptera. From 1848 until 1951 he collaborated with Edgar Leopold Layard (1824-1900), a British diplomat and a naturalist mainly interested in ornithology (Mennell 1892). In addition to massive collections of insects, snails, annelids, birds, and mammals, both Templeton and Layard collected few reptiles. There is one specimen of $D$. bifrenalis in London (BMNH 1894.9.11.20) collected by E.L. Layard himself, but without a precise locality (only Ceylon). Among the species described based on Templeton's collections throughout the country, for example the Common Acacia Blue butterfly, Surendra quercetorum (Moore, 1857) is a species restricted to the dry and intermediate zones. In addition, the type of Oligodon templetonii Günther, 1862 (currently a synonym of Oligodon calamarius (Linnaeus, 1758) and Mytilia templetonii Gray, 1858 (currently a synonym of Rhinophis blythii Kelaart, 1853) were collected by R. Templeton himself, probably in the vicinity of Kandy, as the latter species is restricted to the Kandian mid hills. Among the species, which are based on specimens collected by either Layard or Templeton, most are distributed in the vicinity of Kandy (alt. $500 \mathrm{~m}$ a.s.1.). Interestingly the specimen, NMW 23724 collected from Kandy is very close to the morphology of the lectotype of $D$. bifrenalis as well as to Layard's specimen. In addition to the above three specimens, based on live specimens we observed that the Kandyan population represent the true $D$. bifrenalis along with the populations in dry and intermediate zones (see Fig. 10). Therefore we have to conclude that the lectotype of $D$. bifrenalis was probably collected from either dry zone or surrounding Kandy. In contrast D. wickrorum is restricted to the rest of the southwestern wet zone to a high elevations (alt. 1,000 m a.s.l.), mostly in forests. Therefore, in the map (Fig. 10) we only plotted vouchered or personally observed specimens.

$D$. bifrenalis and $D$. wickrorum sp. nov. are clearly separated species based on morphology, morphometry, and molecular data, the distribution patterns of this species pair is not in accordance with the currently identified biogeographic zonation based on vegetation types and climate of the island. This phenomenon is similar to that which has been observed for D. schokari and D. tristis. D. bifrenalis is sympatric with $D$. tristis in the dry and intermediate zones. In contrast, $D$. wickrorum is sympatric with $D$. sinharajensis, D. schokari and D. caudolineolatus in the wet zone. Previous studies of the biogeographic patterns of less vagile groups in Peninsula India and Sri Lanka (Bossuyt et al. 2004, Lajmi et al. 2019, Mallik et al. 2019) suggested vicariance coupled with allopatry as the main model for speciation in Sri Lanka. Our analysis supports a climate induced allopatric speciation model as the likely cause for the divergence of $D$. wickrorum sp. nov. from $D$. bifrenalis complex (a hypothesis also valid for $D$. schokari and $D$. tristis). The darker, wet, tropical rainforest of the wet zone of Sri Lanka might have favored the dark larger eyes in these diurnal visual predators of the sub-canopy and the understory (personal observations and Pyron et al. 2013).

Wall (1921) examined five specimens of Dendrelaphis bifrenalis (sensu lato) from Sri Lanka, collected from Punagalla (Central Province), Yatiyantota and Balangoda (Sabaragamuwa Province), and Galle (Southern Province). Probably his specimens from Yatiyantota and Galle represent the new species, and the specimens from Balangoda and Punagalla, which are located on the transitional zone between wet and intermediate zones, might be either $D$. bifrenalis or D. wickrorum sp. nov., as we observed several live specimens of $D$. bifrenalis from the dry and intermediate valleys towards the dry zone in the central highlands as 
well as the Knuckles massif. According to Wall (1921), D. bifrenalis was never recorded above 1,000 feet elevation ( $=300 \mathrm{~m}$ a.s.l.). However the holotype of $D$. wickrorum sp. nov. (BMNH 1905.3.25.98) was collected from an elevation of 4,000 feet $(=1,060 \mathrm{~m}$ a.s.1. $)$, the highest elevation record for this species.
Taylor (1950) mentioned a single specimen (EHT-HMS No. 30745 in it) found in Trincomalee, and he noticed "The eye is large but its diameter is distinctly less than its distance from the nostril", an obvious representation of $D$. bifrenalis (in similarity with the specimen of D. bifrenalis found in Waahalhada $50 \mathrm{~km}$ away).

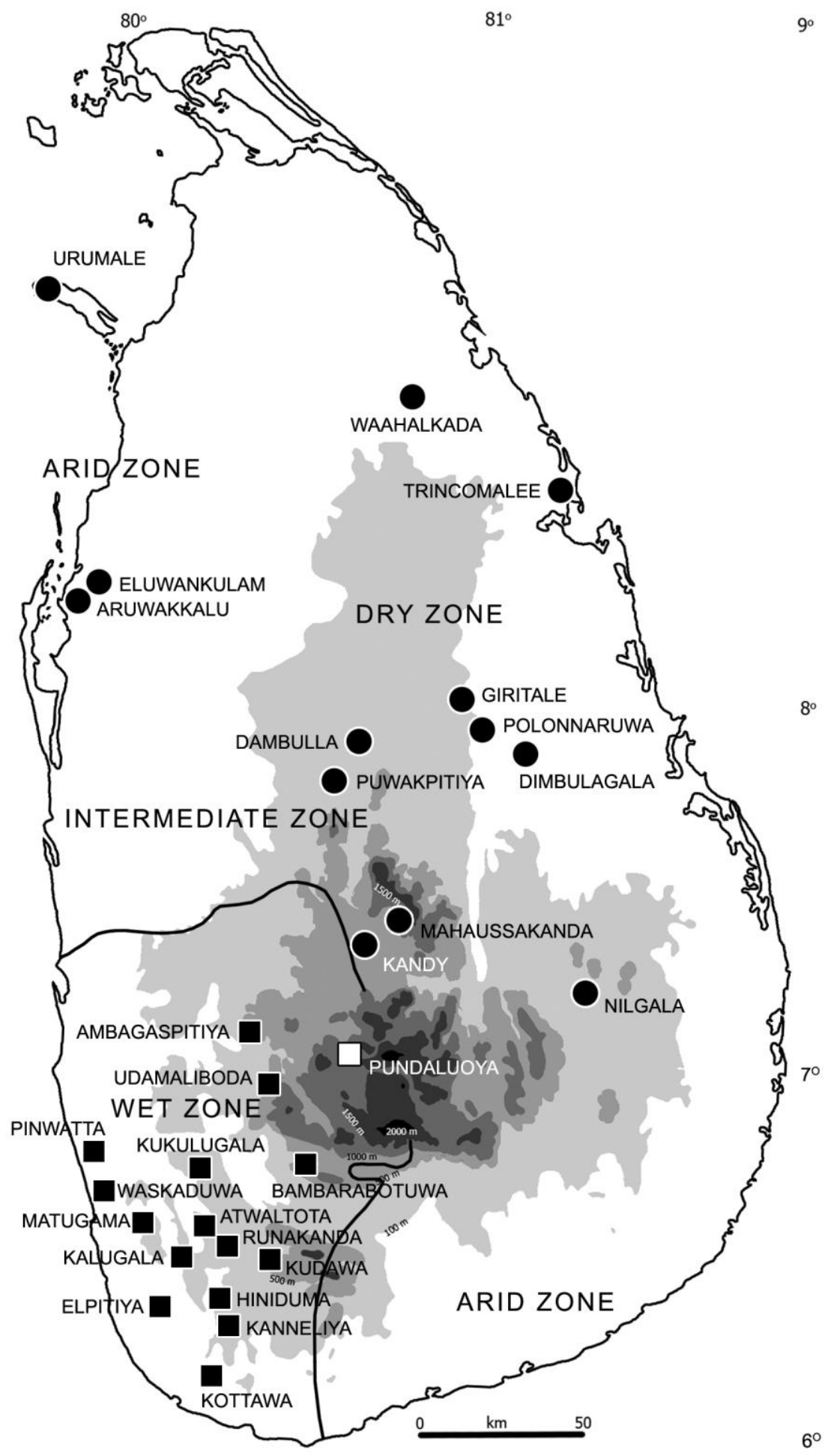

Figure 10. Current distribution map of Dendrelaphis bifrenalis (filled circles) and D. wickrorum sp. nov. (filled squares) in Sri Lanka; holotype locality of D. wickrorum sp. nov. marked with a white square, the lectotype locality of $D$. bifrenalis is unknown [possibly around Kandy]. 
Deraniyagala (1955) further extended the distribution of $D$. bifrenalis from Vavuniya (Northern Province), Mullativu and Trincomalee (Eastern Province), most probably those specimens represent $D$. bifrenalis. He recorded D. bifrenalis (sensu lato) from Veyangoda (Western Province), probably the new species (in similarity with the live specimen of $D$. wickrorum sp. nov. found $10 \mathrm{~km}$ from Ambagaspitiya, Western Province).

Based on recent publications, the records of D. bifrenalis from Nilgala, Uva Province (Karunarathna \& Amarasinghe 2011, Karunarathna et al. 2013) and Eluwankulam, North Western Province (Kumarasinghe et al. 2013) are confirmed with the species identity as $D$. bifrenalis, but the following records of $D$. bifrenalis, here we assign for $D$. wickrorum sp. nov. as one of us (AATA) personally observed and recorded the characters of the same specimens published there in: Kukulugala forest, Sabaragamuwa Province (Karunarathna \& Amarasinghe 2010); Kalugala Forest Reserve, Western Province (Botejue \& Wattavidanage 2012); Udamaliboda forest, Sabaragamuwa Province (Peabotuwage et al. 2012) and Beraliya-Mukalana forest, Southern Province (Karunarathna \& Amarasinghe 2012).

The phylogenetic analysis based on the mitochondrial ND4 region grouped individuals identified as the members of $D$. bifrenalis complex together as a well separated monophyletic group. Similarly, all individuals of $D$. bifrenalis and $D$. wickrorum $\mathrm{sp}$. nov. form well separated distinct groups sister to each other (Fig. 2). We observed concordance between morphometric and phylogenetic divergence across these two species (Figs. $1 \&$ 2), hence we conclude that they are phenotypically and phylogenetically distinct lineages and true taxonomic entities.

Similar to other studies of recently diverged colubrids (Figueroa et al. 2016, Mallik et al. 2019, Jiang et al. 2020), the D. bifrenalis complex might have diversified rapidly as implied by the short internodes throughout much of the tree (this study and in Pyron et al. 2013, Jiang et al. 2020). Nevertheless, we can draw conclusions based on strong nodal support values regarding the placement of the proposed new species (see Mallik et al. 2019, Jiang et al. 2020). Our analysis did not include the probable mainland congener of $D$. bifrenalis complex in Sri Lanka (D. girii), due to the absence of sequences in the global databases and its restricted range. The isolated nature of the $D$. bifrenalis clade in Sri Lankan Dendrelaphis suggesting that there is a good possibility that $D$. girii will cluster with that clade. Our phylogeny further suffers from the absence of two Sri Lankan endemic taxa, $D$. oliveri and $D$. sinharajensis in the analysis. It is high time for a comprehensive phylogenetic study for this divergent, ecologically complex genus, to understand not just the phylogenetic affinities of its members, but also its colonization patterns across Southern and Southeastern Asia.

Among the Sri Lankan Dendrelaphis, D. oliveri is the rarest species. It is only known from a single specimen (holotype). The type locality is 12 miles north of Trincomalee, Ceylon (=Sri Lanka). D. effrenis was also described based on a single specimen collected much earlier (in 1909) than D. oliveri, from Colombo, Sri Lanka. The original description of D. effrenis was written in German by Werner (1909) and is comprehensive enough to distinguish it from other species. Wall (1921) provided an English description, but considered this species could be an aberrant specimen of $D$. caudolineolatus. Smith (1943) synonymised Werner's species with D. caudolineolatus without any discussion, and subsequent authors followed that taxonomic treatment. However, according to the original description, D. effrenis is clearly distinguishable from Dendrelaphis caudolineolatus by having no loreal ( $v s$ present), three postoculars ( $v s$ two), a combination of a red neck and conspicuous red/white cross bars ( $v s$ oblique black stripes on anterior bronze body, that meets mid dorsally forming a ' $\mathrm{V}$ ' shape), a throat with black blotches ( $v s$ blotching absent). Furthermore, D. effrenis is clearly distinguishable by any of the species in a group of Malayan bronzebacks, D. caudolineatus complex, which has similar colour patterns, by having no black longitudinal dorsal stripes ( $v s$ present), no ventrolateral stripe ( $v s$ present), and 129 subcaudals (vs 101-113). The English translation of the German description by Werner (1909) is given in Appendix II.

$$
\text { Wickramasinghe (2016) described }
$$
Dendrelaphis sinharajensis from Sinharaja forest (alt. $285 \mathrm{~m}$ a.s.1.), Sri Lanka, based on a single specimen (NMSL 2016.06.01). A comparison of the holotype and the original description of $D$. sinharajensis with the original description of $D$. effrenis revealed that both 
names were created for the same species. There is only individual variation as follows: the SVL $672 \mathrm{~mm}$, ventrals 174 , temporals $1+3$, and 138 subcaudals in D. sinharajensis (vs SVL $640 \mathrm{~mm}$, ventrals 175 , temporals $2+2$, subcaudals 129 in $D$. effrenis). According to the curator of the $\mathrm{ZMH}$ collection, the holotype of $D$. effrenis, collected by John Hagenbeck from Colombo, Ceylon is missing, misplaced or has been destroyed during the World War II (Pers. comm. Jakob Hallermann, Universität Hamburg Zoologisches Museum). However, the original description of $D$. effrenis is comprehensive enough (Appendix II) to distinguish it from the other valid species of the genus Dendrelaphis. Therefore here we revalidate $D$. effrenis as a distinct species of the genus Dendrelaphis. Furthermore, according to the Article 23 of the ICZN (1999), we synonymise $D$. sinharajensis with $D$. effrenis. To fix the taxonomy of $D$. effrenis, we choose the holotype of $D$. sinharajensis described by Wickramasinghe (2016), as the neotype for Dendrophis effrenis Werner, 1909.

During field surveys we found the third and fourth specimen of $D$. effrenis (not collected) from Kudawa, Sinharaja forest $\left(6^{\circ} 26^{\prime} 09^{\prime \prime} \mathrm{N}\right.$, $80^{\circ} 25^{\prime} 10^{\prime \prime} \mathrm{E}$; alt. $350 \mathrm{~m}$ a.s.1.), and Athwalthota, Mathugama (6 $6^{\circ} 31^{\prime} 13^{\prime \prime} \mathrm{N}, 80^{\circ} 16^{\prime} 53^{\prime \prime} \mathrm{E}$; alt. $50 \mathrm{~m}$ a.s.1.), Sabaragamuwa Province, Sri Lanka (Fig. 11). The type locality of the species is given as Colombo (Werner 1909). It may have been collected from one of several patches of rainforests near Colombo (e.g. Dombagaskanda, Waga Forest Reserve etc.) as this species may have been widely distributed in the lowland rainforests (alt. 50-350 $\mathrm{m}$ a.s.1.) during its time of description. The possibility also exists that the location of the specimen was erroneously assigned disregarding the climatic and biogeographic heterogeneity of the island.

An identification key for the Dendrelaphis species in Sri Lanka is given below.

1. (a) Midbody scale in 13 rows ....................... 2

(b) Midbody scale in 15 rows

3

2. (a) Loreal present, 149 ventrals, 119-128 subcaudals, and temporal stripe present ............... D. caudolineolatus

(b) Loreal absent, 174-175 ventrals, 129-139 subcaudals, and temporal stripe absent

D. effrenis

3. (a) Loreal present ... 4

(b) Loreal absent D. oliveri
4. (a) Single loreal scale ................................ 5

(b) Two loreal scales .................................. 6

5. (a) 155-177 ventrals, interparietal spot absent ..... D. schokari

(b) 178-198 ventrals, interparietal spot present ... D. tristis

6. (a) temporal stripe continues behind neck, prominent black transverse dorsolateral bars on the anterior $1 / 4^{\text {th }}$ of body, ventro-lateral stripe stopping at the level of anal plate, wide and flat snout, eye small and eye diameter $<$ eye-nostril distance .................................... D. bifrenalis (b) temporal stripe stopping just beyond the neck, no black transverse dorsolateral bars on the anterior $1 / 4^{\text {th }}$ of body, ventro-lateral stripe continuing up to the tail, narrow and rounded snout, eye large and eye diameter $>$ eye-nostril distance D. wickrorum sp. nov.

\section{Acknowledgements}

We thank the Department of Wildlife Conservation (Permit no. WL/3/2/74/15) and Department of Forest Conservation (R\&E/RES/NFSRCM/2015-04) for granting research permits to DD, SK and SS to carry out field tissue sampling. We thank Ivan Ineich (Muséum national d'Histoire naturelle, Paris), Suranjan Karunarathna (NEET), Philip Bowles (IUCN), Mendis Wickramasinghe (HFS), and an anonymous reviewer for the review of the manuscript and critical comments. Patrick Campbell and David Gower at BMNH, UK; Varad Giri formerly at the BNHS, India; Alan Resetar at FMNH, USA; Andreas Schmitz at MHNG, Switzerland; Annemarie Ohler and Alain Dubois at MNHN, France; Uwe Fritz and Edgar Lehr at MTKD in Germany; Nanda Wickramasinghe (former director), Sanuja Kasthuriarachchi (director), Lankani Somaratne, Chamalka Kothalawala, Chandrika Munasinghe, Rasika Dasanayake, Ravindra Wickramanayake, and P. Gunasiri at NMSL, Sri Lanka; Silke Schweiger and Georg Gassner at NMW, Austria; Esther Dondorp, Pim Arntzen and Ronald de Ruiter at RMNH, The Netherlands; Gunther Köhler and Linda Acker at SMF, Germany; and George Zug, Kenneth Tighe and Ronald Heyer at USNM are acknowledged for facilitating the in-house study of specimens under their care. Anslem de Silva, Suranjan Karunarathna, Vimukthi Weeratunga, Nadeeka Hapuarachchi, Madura De Silva and Mendis Wickramasinghe for valuable assistance in numerous stages of the study. Special thanks to Mendis Wickramasinghe for providing two paratypes, 


\section{Plate 36}

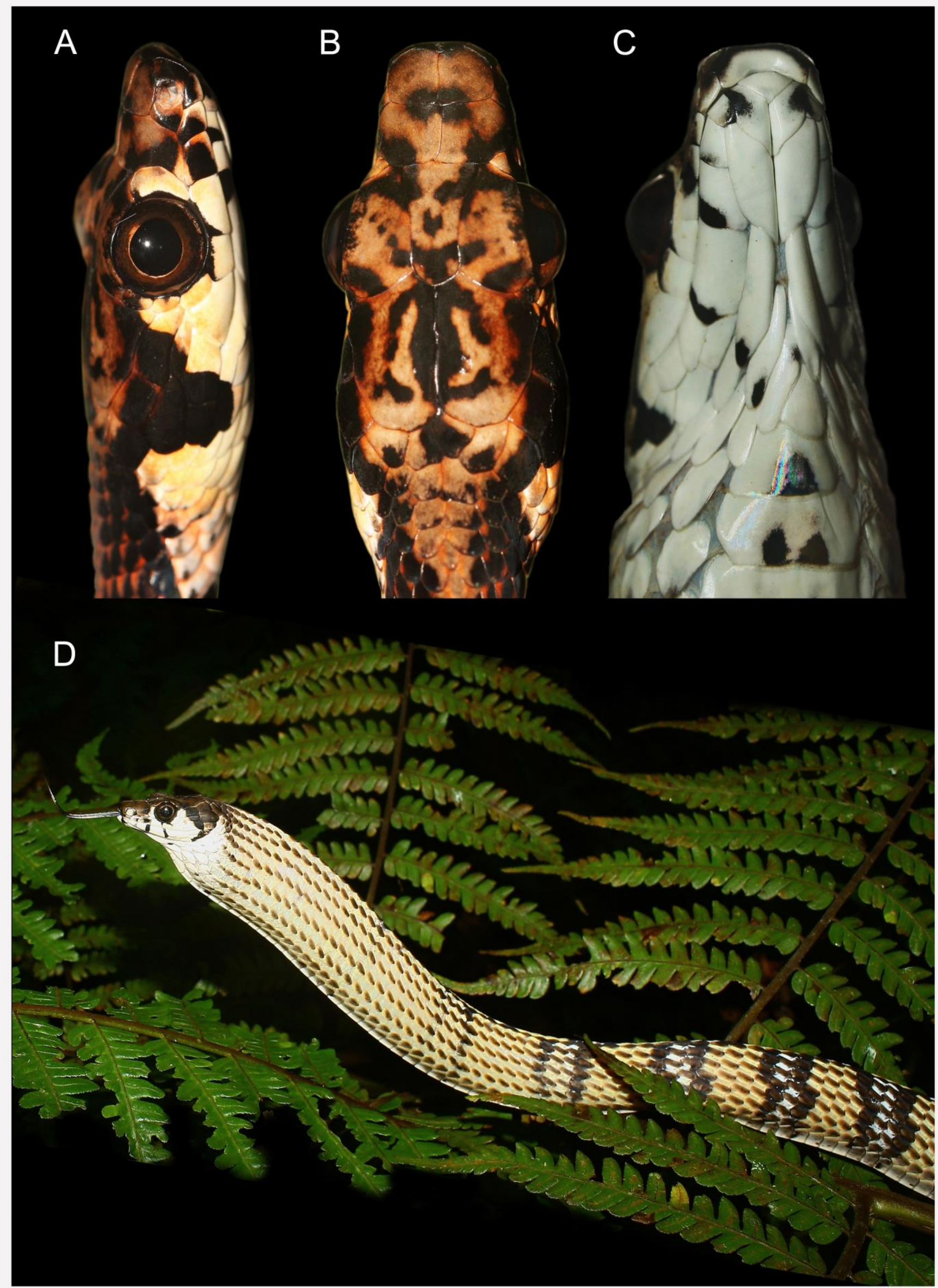

Figure 11. Dendrelaphis effrenis (Werner, 1909) male (not collected), head in (A) lateral view, (B) dorsal view from Kudawa, Sinharaja Forest, Ratnapura District, Sri Lanka; female (not collected), head in (C) ventral view and (D) the anterior body, from Athwalthota Forest, Matugama, Kalutara District, Sri Lanka. 
and nicely illustrate the line drawing. Also, we wish to thank Nuwan Madushanka, Dushmantha Kulathunga, Tharidu Ranasinghe, Rev. Hatangala Medanananda Thero, Mithun Chanaka, and Vishwa Sachith for the support in the field; Divanka Randula and Himesh Jayasinghe assisted in taking the photographs. Tharindu Premachandra, Shynika Lasanthi and Sanjaya Weerakkody at the Department of Zoology, UOC assisted in the genetic and phylogenetic analysis. Part of the funding for the fieldwork was provided by the Wildlife Conservation Society of Galle (WCSG). We also thank J. Supriatna and the staff of the Research Center for Climate Change, University of Indonesia, and the members of the Avian Evolution Node and the Laboratory for Molecular Ecology and Evolution, University of Colombo for their support.

\section{Literature cited}

Beolens, B., M. Watkins, and M. Grayson (2011). The Eponym Dictionary of Reptiles. Johns Hopkins University Press, Baltimore: 296 pp.

Bossuyt, F., M. Meegaskumbura, N. Beenaerts, D.J. Gower, R. Pethiyagoda et al. (2004). Local endemism within the Western Ghats-Sri Lanka biodiversity hotspot. Science, 306 (5695): 479-481.

Botejue, W.M.S. and J. Wattavidanage (2012). Herpetofaunal diversity and distribution in Kalugala proposed forest reserve, Western province of Sri Lanka. Amphibian \& Reptile Conservation, 5 (2): 65-80.

Boulenger, G.A. (1890). Fauna of British India, including Ceylon and Burma. Reptilia and Batrachia. Taylor and Francis, London, UK: $541 \mathrm{pp}$.

Boulenger, G.A. (1894). Catalogue of the Snakes in the British Museum (Natural History). Volume II, Containing the Conclusion of the Colubrida Aglypha. British Museum of Natural History, London: 382 pp.

Daudin, F.M. (1803). Histoire Naturelle Générale et Particulière des Reptiles. Volume 6, Paris: $447 \mathrm{pp}$.

Deraniyagala, P.E.P. (1955). A Colored Atlas of Some Vertebrates from Ceylon. Volume 3 (Serpentoid Reptilia). Colombo National Museums, Sri Lanka: 200 pp.

De Silva, P.H.D.H. (1980). Snakes Fauna of Sri Lanka, with special reference to skull, dentition and venom in snakes. Sri Lanka National Museums, Colombo: 472 pp.
Dowling, H.G. (1951). A proposed standard system of counting ventrals in snakes. British Journal of Herpetology, 1 (5): 97-98.

Ferguson, W.M. (1877). Reptile Fauna of Ceylon. Letter on a collection sent to the Colombo Museum. Government Press, Colombo: 42 pp.

Fernando S.P., D.E. Irwin, and S.S. Seneviratne (2016). Phenotypic and genetic analysis support distinct species status of the Redbacked Woodpecker (Lesser Sri Lanka Flameback: Dinopium psarodes) of Sri Lanka. Auk: Ornithological Advances, 133 (3): 1-15.

Figueroa, A., A. Mckelvy, L.L Grismer, C. Bell, and S. Lailvaux (2016). A species-level phylogeny of extant snakes with description of a new colubrid subfamily and genus. PlosOne, 11 (9): e016107.

Forstner, M.R.J., S.K. Davis, and E. Arevalo (1995). Support for the hypothesis of Anguimorph Ancestry for the Suborder Serpentes from Phylogenetic Analysis of Mitochondrial DNA Sequences. Molecular Phylogenetics \& Evolution, 4 (1): 93-102.

Gray, J.E. (1834). Illustrations of Indian Zoology, chiefly selected from the collection of MajorGeneral Hardwicke, F.R.S. Volume 2. Adolphus Richter \& Co., London (18331834): $263 \mathrm{pp}$.

Gray, J.E. (1858). On a new genus and several new species of Uropeltidae in the collection of the British Museum. The Annals and Magazine of Natural History, Series 3, 2 (7-12): 376-381.

Günther, A.C.L.G. (1858). Catalogue of colubrine snakes in the collection of the British Museum. British Museum (Natural History), London: $281 \mathrm{pp}$.

Günther, A. (1862). On new species of snakes in the collection of the British Museum. The Annals and Magazine of Natural History, Series 3, 9 (49): 52-59.

Günther, A. (1869). Report on two collections of Indian reptiles. Proceedings of the Zoological Society of London, 1869: 500-507.

ICZN (1999). International Code of Zoological Nomenclature, $4^{\text {th }}$ edition. International Trust for Zoological Nomenclature, London: $306 \mathrm{pp}$.

Jiang, K., J.-L. Ren, J.-F. Guo, Z. Wang, L. Ding et al. (2020). A new species of the genus Dendrelaphis (Squamata: Colubridae) from Yunnan Province, China, with discussion of the occurrence of D. cyanochloris (Wall, 1921) in China. Zootaxa, 4743 (1): 1-20.

Karunarathna, D.M.S.S. and A.A.T. Amarasinghe (2010). Reptile diversity of a fragmented lowland rain forest patch in Kukulugala, Ratnapura District, Sri Lanka. Taprobanica, 2 (2): 86-94. 
Karunarathna, D.M.S.S. and A.A.T. Amarasinghe (2011). A preliminary survey of the reptile fauna in Nilgala forest and its vicinity, Monaragala District, Sri Lanka. Taprobanica, 3 (2): 69-76.

Karunarathna, D.M.S.S. and A.A.T. Amarasinghe (2012). Reptile diversity in Beraliya Mukalana proposed Forest Reserve, Galle District, Sri Lanka. Taprobanica, 4 (1): 20-26.

Karunarathna, D.M.S.S., S.M. Henkanatthegedara, A.A.T. Amarasinghe, and A. de Silva (2013). Impact of vehicular traffic on herpetofaunal mortality in a savannah forest, Eastern Sri Lanka. Taprobanica, 5 (2): 111-119.

Kearse, M., R. Moir, A. Wilson, S. Stones-Havas, M. Cheung et al. (2012). Geneious Basic: an integrated and extendable desktop software platform for the organization and analysis of sequence data. Bioinformatics, 28 (12): $1647-$ 1649.

Kelaart, E.F. (1853) Prodromus Faunae Zeylanicae, being contributions to the zoology of Ceylon. volume 1. published by the author, Colombo: $197 \mathrm{pp}$.

Kuhl, H. (1820). Beiträge zur Zoologie und vergleichenden Anatomie. Hermannsche Buchhandlung, Frankfurt: 152 pp.

Kumar, S., G. Stecher, and K. Tamura (2016). MEGA7: Molecular Evolutionary Genetics Analysis version 7.0 for bigger datasets. Molecular Biology \& Evolution, 33 (7): 18701874.

Kumarasinghe, A., W.A.A.D.G. Pradeep, P.I.K.. Peabotuwage, R.G.A.T.S. Wickramaarachchi, S. Somarathne et al. (2013). An attempt to reduce impacts of limestone quarries through biodiversity assessment and translocation: A case study at the Holcim Limestone Quarry Site in Puttalam, Sri Lanka. Asian Journal of Conservation Biology, 2 (1): 3-20.

Lajmi, A., R. Bansal, V. Giri, and P. Karanth (2019). Phylogeny and biogeography of the endemic Hemidactylus geckos of the Indian subregion suggest multiple dispersals from Peninsular India to Sri Lanka. Zoological Journal of the Linnean Society, 186 (1): 286301.

Lanfear, R., B. Calcott, S.Y. Ho, and S. Guindon (2012). PartitionFinder: combined selection of partitioning schemes and substitution models for phylogenetic analyses. Molecular Biology \& Evolution, 29 (6): 1695-1701.

Larkin, M.A, G. Blackshields, N.P. Brown, R. Chenna, P.A. McGettigan et al. (2007). Clustal W and Clustal X version 2.0. Bioinformatics, 23 (21): 2947-2948.
Leviton, A.E. (1970). The Philippine snakes of the genus Dendrelaphis (Serpentes: Colubridae). Contributions to a review of Philippine snakes, XII. Philippine Journal of Science, 97 (4): 371-396.

Linnaeus, C. (1758). Systema natura per regna tria natura, secundum classes, ordines, genera, species, cum characteribus, differentiis, synonymis, locis. Tomus I. Editio decima, reformata. Laurentii Salvii, Holmiæ. $10^{\text {th }}$ Edition: $824 \mathrm{pp}$.

Mallik, A.K., N.S. Achyuthan, S.R. Ganesh, S.P. Pal, S.P. Vijayakkumar et al. (2019). Discovery of a deeply divergent new lineage of vine snake (Colubridae: Ahaetuliinae: Proahaetulla gen. nov) from the southern Western Ghats of Peninsular India with a revised key for Ahaetuliinae. PlosOne, 14 (7): e0218851.

Meise, W. and W. Henning (1932). Die Schlangengattung Dendrophis. Zoologischer Anzeiger, 99 (11 \& 12): 273-297

Mennell, P. (1892). The dictionary of Australasian biography: comprising notices of eminent colonists from the inauguration of responsible government down to the present time (18551892). Hutchinson \& co., London: 542 pp.

Nash, R., H.C.G. Ross, and R. Vane-Wright (1980). Contributions to natural history by Dr. Robert Templeton, R.A., with special reference to Ceylon. Irish Naturalists' Journal, 20 (1): 31-33.

Peabotuwage, I., I.N. Bandara, D. Samarasinghe, N. Perera, M. Madawala et al. (2012). Range extension for Duttaphrynus kotagamai (Amphibia: Bufonidae) \& a preliminary checklist of herpetofauna from the Uda Mäliboda Trail in Samanala Nature Reserve, Sri Lanka. Amphibian \& Reptile Conservation, 5 (2): 52-64.

Pethiyagoda, R. (2007). Pearls, Spices, and Green Gold: An Illustrated History of Biodiversity Exploration in Sri Lanka. WHT Publications Pvt. Ltd., Colombo: 215 pp.

Pyron, R.A., H.K.D. Kandambi, C.R. Hendry, V. Pushpamal, F.T. Burbrink et al. (2013). Genus-level phylogeny of snakes reveals the origins of species richness in Sri Lanka. Molecular Phylogenetics \& Evolution, 66 (3): 969-978.

Rambaut, A., M.A. Suchard, D. Xie, and A.J. Drummond (2014). Tracer v1.6, Available from http://beast.bio.ed.ac.uk/Tracer

R Development Core Team (2012). R: A Language and Environment for Statistical Computing. R Foundation for Statistical Computing, Austria. 
Ronquist, F. and J.P. Huelsenbeck (2003). MrBayes 3: Bayesian phylogenetic inference under mixed models. Bioinformatics, 19 (12): $1572-1574$.

Seutin, G., B.N. White, and P.T. Boag (1991). Preservation of avian blood and tissue samples for DNA analyses. Canadian Journal of Zoology, 69 (1): 82-90.

Stamatakis, A. (2014). RAxML version 8: a tool for phylogenetic analysis and post-analysis of large phylogenies. Bioinformatics, 30 (9): 1312-1313.

Smith, M.A. (1943). The Fauna of British India, Ceylon and Burma, Including the whole of the Indo-Chinese Sub-Region. Reptilia and Amphibia. 3 (Serpentes). Taylor \& Francis, London: 583 pp.

Tamura, K., M. Nei, and S. Kumar (2004). Prospects for inferring very large phylogenies by using the neighbor-joining method. Proceedings of the National Academy of Sciences USA, 101 (30): 11030-11035.

Taylor, E.H. (1950). The Snakes of Ceylon. University of Kansas Science Bulletin, 33 (14): 519-603.

Uetz, P., S. Cherikh, G. Shea, I. Ineich, P.D. Campbell et al. (2019). A global catalog of primary reptile type specimens. Zootaxa, 4695 (5): 438-450.

van Rooijen, J. and G. Vogel (2008a). Contributions to a review of the Dendrelaphis pictus complex (Serpentes: Colubridae) -1 . Description of a sympatric species. AmphibiaReptilia, 29 (1): 101-115.

van Rooijen, J. and G. Vogel (2008b). An investigation into the taxonomy of Dendrelaphis tristis (Daudin, 1803): revalidation of Dipsas schokari (Kuhl, 1820) (Serpentes, Colubridae). Contributions to Zoology, 77 (1): 33-43.

van Rooijen, J. and G. Vogel (2009). A multivariate investigation into the population systematics of Dendrelaphis tristis (Daudin, 1803) and Dendrelaphis schokari (Kuhl, 1820): revalidation of Dendrophis chairecacos Boie, 1827 (Serpentes: Colubridae). The Herpetological Journal, 19 (4): 193-200.

van Rooijen, J. and G. Vogel (2012). A revision of the taxonomy of Dendrelaphis caudolineatus (Gray, 1834) (Serpentes: Colubridae). Zootaxa, 3272: 1-25.

Vogel, G. and J. van Rooijen (2008). Contributions to a review of the Dendrelaphis pictus (Gmelin, 1789) complex-2. the eastern forms (Serpentes: Colubridae). Herpetozoa, 21 (1\& 2): 3-29.
Vogel, G. and J. van Rooijen (2011a). Contributions to a Review of the Dendrelaphis pictus (Gmelin, 1789) Complex (Serpentes: Colubridae)-3. The Indian Forms, with the Description of a New Species from the Western Ghats. Journal of Herpetology, 45 (1): 100-110.

Vogel, G. and J. van Rooijen (2011b). A new species of Dendrelaphis (Serpentes: Colubridae) from the Western Ghats - India. Taprobanica, 3 (2): 77-85.

Wall, F. (1921). Ophidia Taprobanica or the Snakes of Ceylon. Colombo Museum, H. R. Cottle, government printer, Colombo: 581 pp.

Werner, F. (1909). Über neue oder seltene Reptilien des Naturhistorischen Museums in Hamburg. I. Schlangen. Jahrbuch der hamburgischen Wissenschaftlichen Anstalten. Mitteilungen aus dem Naturhistorischen Museum in Hamburg, 1908 (26): 205-247.

Wikramasinghe, L.J.M. (2016). A new canopydwelling species of Dendrelaphis (Serpentes: Colubridae) from Sinharaja, World Heritage Site, Sri Lanka. Zootaxa, 4162 (3): 504-518. 
Appendix I. Other specimens examined

D. bifrenalis (13 ex.): Sri Lanka: BMNH 1946.1.6.4 (lectotype designated herein), 1946.1.10.19 (paralectotype of D. bifrenalis), 94.9.11.20, MHNG 762.75, 743.36, FMNH 142366; Kandy: NMW 23724; Polonnaruwa: NMSL uncat. (WHT 1752-A), SMF 25483; Mahaussakanda: DWC 2020.05.02; Maha-Waskaduwa: DWC 2020.05.05; Girithale: DWC 2020.05.06; Aruwakkalu, Puttalam: DWC 2020.05.07.

D. caudolineolatus (2 ex.): Sri Lanka: BMNH 1946.1.23.21 \& 1858.2.17.19 (syntypes).

D. effrenis (1 ex.): Sri Lanka: NMSL 2016.06.01 (neotype designated herein, holotype of $D$. sinharajensis).

D. girii (6 ex.): India: Karnataka: BNHS 3494 (holotype), 3495 (paratype); Tamil Nadu: BNHS 3273 (paratype); Maharashtra: 3423, 3491, 3493 (paratypes).

D. oliveri (1 ex.): Sri Lanka: FMNH 123726 (holotype).

D. schokari (23 ex.): Sri Lanka: RMNH 842 (neotype designated by van Rooijen \& Vogel 2008), 7066ab, NMW23669:1-2, 24382:2-4, MNHN-RA 1890.0065, BMNH 1969.2781, SMF 18672, 32366, 62074, 62076, 70285, MHNG 762.73, 1198.50-51, 1198.53, 1198.55, MTKD 10440, 10646, 15438.

D. tristis (7 ex.): India: SMF 58442 (neotype designated by van Rooijen \& Vogel 2008); Sri Lanka: BMNH 1955.1.9.80, 93.10.6.1, 1972.2.18.3, ZMA 21563, SMF 18671, 32367.

Appendix II. English translation of the original description of Dendrophis effrenis Werner, 1909.

\section{Dendrophis effrenis n. sp.}

Colombo, Ceylon (leg. JoHn HAGENBECK 1904).

Dor. 13, V. 175, Anal divided, Sc. 129/129+1.

Rostral twice as wide as long. Internasals as long as prefrontals. Frontal 1.66 times as long as wide, longer as its distance from tip of snout, as long as parietals. No loreal, 1 preocular, 3 postoculars, temporals $2+2,4$ infralabials in contact with the anterior chin shields, which are shorter than the posteriors. Eye large, but its diameter only as long as its distance from posterior margin of the hole in the nose.

Colouration (in formalin): Upper side blackish gray, neck scales with narrower and wider red bands, so that in the anterior part of the body 7 dark bands can be seen separate by wide spaces. Rostral dorsal with dark margins; $1^{\text {st }}$ and $2^{\text {nd }}$ supralabials dark; a broad dark band from the eye to the corner of the mouth and a little bit beyond it. Lower labials partially spotted black, throat just as well. Ventrals with dark dots.

Total length $884 \mathrm{~mm}$, tail $244 \mathrm{~mm}$.

Published date: 21 May 2020 